\title{
Review \\ Understanding Retinoblastoma Post-Translational Regulation for the Design of Targeted Cancer Therapies
}

\author{
Radoslav Janostiak ${ }^{1,2,+} \mathbb{0}$, Ariadna Torres-Sanchez ${ }^{1,2}$, Francesc Posas ${ }^{1,2, *}$ and Eulàlia de Nadal ${ }^{1,2, *}$ \\ 1 Institute for Research in Biomedicine (IRB Barcelona), The Barcelona Institute of Science and Technology, \\ Baldiri Reixac, 10, 08028 Barcelona, Spain; radoslav.janostiak@irbbarcelona.org (R.J.); \\ ariadna.torres@irbbarcelona.org (A.T.-S.) \\ 2 Department of Medicine and Life Sciences (MELIS), Universitat Pompeu Fabra (UPF), 08003 Barcelona, Spain \\ * Correspondence: francesc.posas@irbbarcelona.org (F.P.); eulalia.nadal@irbbarcelona.org (E.d.N.); \\ Tel.: +34-93-403-4810 (F.P.); +34-93-403-9895 (E.d.N.) \\ † Current address: BIOCEV, 1st Faculty of Medicine, Charles University, 25250 Vestec, Czech Republic.
}

Citation: Janostiak, R.; Torres-Sanchez, A.; Posas, F.; de Nadal, E. Understanding Retinoblastoma Post-Translational Regulation for the Design of Targeted Cancer Therapies. Cancers 2022, 14, 1265. https://doi.org/10.3390/ cancers14051265

Academic Editor: David Wong

Received: 8 February 2022

Accepted: 25 February 2022

Published: 28 February 2022

Publisher's Note: MDPI stays neutral with regard to jurisdictional claims in published maps and institutional affiliations.

Copyright: (C) 2022 by the authors. Licensee MDPI, Basel, Switzerland. This article is an open access article distributed under the terms and conditions of the Creative Commons Attribution (CC BY) license (https:// creativecommons.org/licenses/by/ $4.0 /)$.
Simple Summary: $\mathrm{Rb} 1$ is a regulator of cell cycle progression and genomic stability. This review focuses on post-translational modifications, their effect on $\mathrm{Rb} 1$ interactors, and their role in intracellular signaling in the context of cancer development. Finally, we highlight potential approaches to harness these post-translational modifications to design novel effective anticancer therapies.

\begin{abstract}
The retinoblastoma protein ( $\mathrm{Rb} 1)$ is a prototypical tumor suppressor protein whose role was described more than 40 years ago. Together with p107 (also known as RBL1) and p130 (also known as RBL2), the Rb1 belongs to a family of structurally and functionally similar proteins that inhibits cell cycle progression. Given the central role of $\mathrm{Rb} 1$ in regulating proliferation, its expression or function is altered in most types of cancer. One of the mechanisms underlying Rb-mediated cell cycle inhibition is the binding and repression of E2F transcription factors, and these processes are dependent on $\mathrm{Rb} 1$ phosphorylation status. However, recent work shows that Rb1 is a convergent point of many pathways and thus the regulation of its function through post-translational modifications is more complex than initially expected. Moreover, depending on the context, downstream signaling can be both E2F-dependent and -independent. This review seeks to summarize the most recent research on $\mathrm{Rb} 1$ function and regulation and discuss potential avenues for the design of novel cancer therapies.
\end{abstract}

Keywords: retinoblastoma; cell cycle; cancer therapies

\section{Introduction}

The discovery of the Retinoblastoma-associated protein $1(\mathrm{Rb} 1)$ in the late 1970s was an important milestone in understanding cancer development [1-3]. Until then, cancer was believed to arise because of dominantly activated oncogenes [4]. However, studies of hereditary retinoblastoma tumors brought about the discovery of Rb1 as a prototype tumor suppressor gene whose homozygous inactivation leads to the development of tumors [5-7]. The $R b 1$ locus is located on the $q$ arm of chromosome 13, and the presence of genetic rearrangements in this region in retinoblastoma tumors was one of the crucial pieces of evidence for the identification of $\mathrm{Rb} 1$ as a key player in the development of such tumors $[6,7]$.

The product of $R b 1$ comprises 928 amino acids, has a molecular weight of $106 \mathrm{kDa}$, and belongs to a family of structurally related molecules called pocket domain proteins. The family consists of Rb1 and its two paralogs Rbl1 (p107) and Rbl2 (p130), which share similar domain organization, although several differences make Rbl1 and Rbl2 more related to each other than to $\mathrm{Rb} 1[8,9]$.

$\mathrm{Rb} 1$ protein has several domains that are crucial for its function and interactions. In the past, the central pocket domain (residues 379 -792) and C-terminal domain (residues 792 — 926) 
were considered the most important parts for Rb1 function [10], namely arrest of cell cycle progression through inhibition of E2F1 function [11]. In addition to its canonical function, Rb1 plays a key role in regulating other cellular processes such as differentiation, maintenance of genome stability, and immune evasion [12-14]. Rb1 function is deregulated in most types of human cancer through genetic alteration or, more often, through alteration of upstream pathway components that inactivate its function through post-translational modifications $[15,16]$.

In this review, we describe the canonical and non-canonical functions of Rb1, its alteration in human cancers, and the post-translational modifications that are crucial for its regulation. Finally, we discuss how Rb1 post-translation modifications could be harnessed to design novel anticancer therapies.

\section{Rb1 Function and Downstream Signaling}

To date, more than $300 \mathrm{Rb} 1$ interactors have been identified, thus indicating that this protein is involved in multiple signaling complexes [17]. Although the most studied signaling event is the cell cycle-dependent binding of $\mathrm{Rb} 1$ to $\mathrm{E} 2 \mathrm{~F}$ transcriptional factors (E2F-dependent signaling), $\mathrm{Rb} 1$ regulates other signaling pathways that can be roughly classified as E2F-independent.

\subsection{E2F-Dependent Signaling}

The key event for the regulation of E2F1-dependent downstream signaling is the binding of $\mathrm{Rb} 1$ to E2F1. This interaction and its consequences have been studied extensively and the mechanisms involved are well characterized.

Initial binding analyses and structural experiments determined two structural features that delineate the binding of Rb1 to E2F1, namely the central pocket and C-terminal domains [10,18,19] (Figure 1A). The central pocket domain of Rb1 is responsible for binding to E2F1. The relevance of this domain for this binding and for regulating E2F1-mediated transcription was shown by in vitro and in vivo studies, as well as by crystallography. The central pocket domain of Rb1 (residues 379-792) consists of two cyclin folds (Boxes A and B) connected by a flexible linker [10]. This region binds to an 18 amino acid-long peptide within the transactivation domain of E2F1 (residues 409-426) [10]. This interaction is crucial for binding, as well as for inhibiting E2F1 transcriptional activity in vitro; however, it is insufficient to fully inhibit E2F1-mediated transcription in vivo, thereby suggesting further interaction requirements [20-22]. This additional structural and functional interaction is provided by the C-terminal domain of Rb1, which does not adopt a particular structure by itself. Instead, two regions in this domain (residues 786-800 and 829—846) bind to a heterodimeric structure formed by the E2F1 coiled-coil marked box (CCMB) domain (residues 200-301) and to the CCMB domain (residue 199-350) of the transcription factor DP1 (TFDP1), to form a stable complex [23]. The binding of Rb1 to E2F1 then results in inhibition of E2F1-mediated transcription of cell cycle progression genes, such as Cyclin A, Cyclin E and cdc25, which ultimately leads to cell cycle arrest and inhibition of cell proliferation $[11,24,25])$.

Structure and interaction surfaces are regulated by phosphorylation by CKDs. There are two main regions on $\mathrm{Rb} 1$ that are phosphorylated by CDKs - central pocket domain and C-terminal domain. Phosphorylation of residues within these regions (T356, T373, S788, S795, S807, S811, S821, S826) leads to disruption of Rb1 with E2F1 interaction and transcriptional activation of cell cycle regulating genes (More detailed description of these phosphorylations is in following sections). 


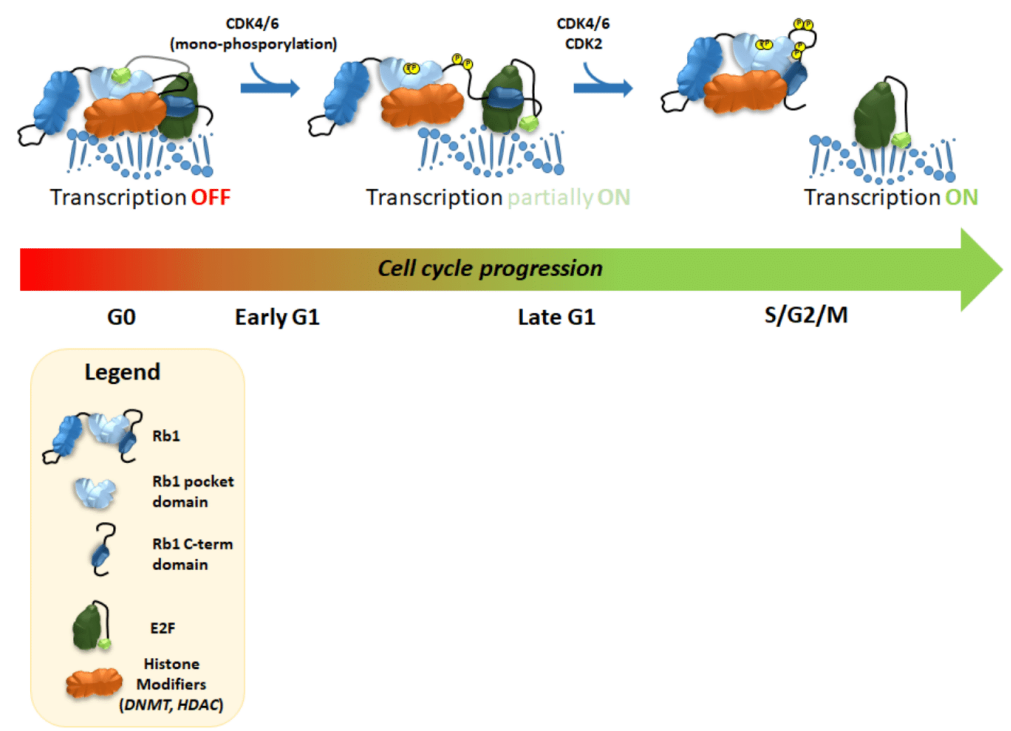

(A)

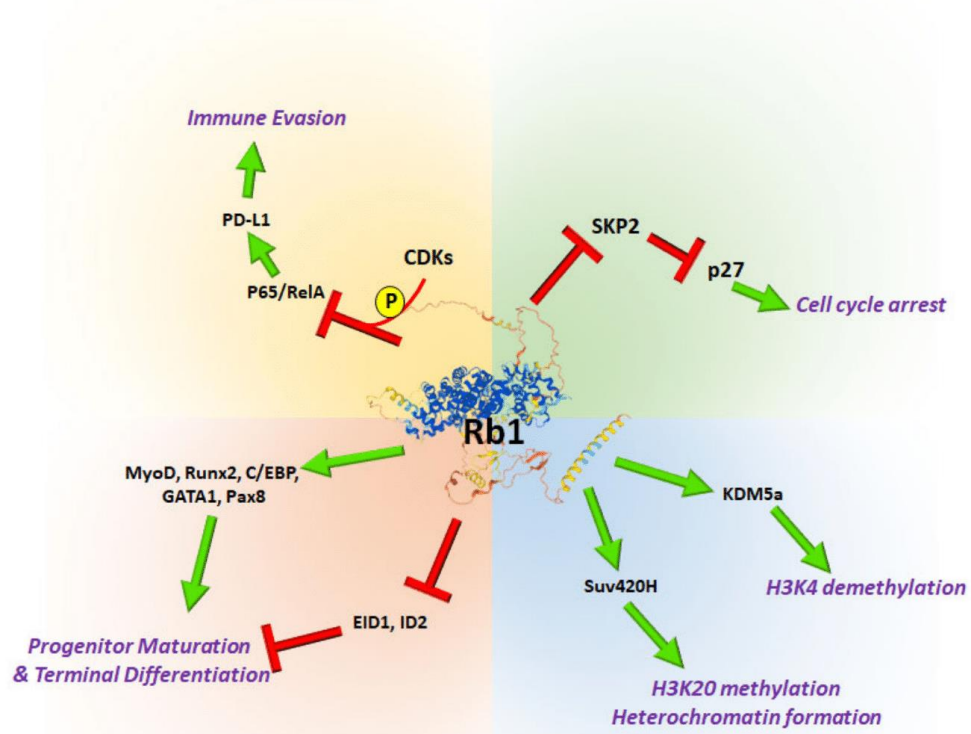

(B)

Figure 1. $\mathrm{Rb} 1$ regulation during cell cycle progression and downstream signaling (A) E2F regulation by $\mathrm{Rb} 1$. In the absence of phosphorylation, $\mathrm{Rb} 1$ binds to $\mathrm{E} 2 \mathrm{~F}$ transcription factor through the Rb1 pocket and C-terminal domains and inhibits its transcriptional activity. Moreover, Rb1 recruits histone modification enzymes such as DNMT1, HDACs or Suv39H to block transcription from E2F target promoters by stimulating a repressive chromatin state. Upon entry into cell cycle, Rb1 is phosphorylated by CDK4/6-Cyclin D complexes, which allows partial transcription of E2F-stimulated genes. In late $\mathrm{G} 1$ and $\mathrm{S}$ phases, $\mathrm{Rb} 1$ is hyperphosphorylated by CDK4/6-Cycline D and CDK2-Cycline E complexes, which leads to the disassociation of $\mathrm{Rb} 1$ from E2F, full stimulation of E2F target genes, and cell cycle progression. (B) E2F-independent Rb1 function: Beyond binding and inhibiting E2F, $\mathrm{Rb} 1$ was implicated in the regulation of several signaling pathways: (i) it binds and inhibits p65 transcription factor, which leads to impairment of PD-L1 expression and immune evasion; (ii) it stabilizes cyclin-dependent kinase inhibitor p27 by sequestering SKP2 and targeting it for degradation; (iii) it stimulates terminal differentiation of multiple cell lineages by activating differentiation transcription factors (TFs) such as MyoD, Runx2, GATA1, Pax8 or impairing the function of differentiation inhibitory TFs such as EID1 or ID2; and (iv) it regulates heterochromatinization by recruiting and stimulating the activity of KDM5a demethylase and SUV420H methylase. 
$\mathrm{Rb} 1$-mediated inhibition of E2F transcriptional activity is mediated by two distinct molecular mechanisms. First, Rb1 binding to the transactivation domain of E2F blocks the recruitment of general transcription factors and histone acetylases that are necessary for transcription initiation [26,27]. Second, Rb1-bound E2F recruits numerous histonemodifying and chromatin-remodeling factors to E2F-target promoters, thus altering chromatin structure and configuration. It was shown that these factors contain the so-called LXCXE motif, which associates with a structure known as the "LXCXE- binding cleft" within the Rb1 central pocket domain $[19,28]$. Through this domain, Rb1 binds and recruits several members of histone deacetylases (HDACs) and histone methylases. To date, the interaction of Rb1 and four members of the HDAC family (HDAC1, 2, 3, 5) has been described [28-31] and evidence points to the interaction of Rb1 and HDACs being crucial for transcriptional silencing of E2F1-target promoters.

After the recruitment of HDACs to E2F-target promoters, the deacetylases act on the surrounding histone tail residues, thus repressing E2F-mediated transcription. Moreover, this repression is dependent on $\mathrm{Rb} 1$ and also on HDAC activity, as trichostatin A treatment (HDACi) impairs this inhibition [29,30]. Recently, the interaction between HDAC5 and $\mathrm{Rb} 1$ was reported to be crucial for the transcriptional repression of pro-oncogenic genes. Furthermore, deletion of HDAC5 results in the impairment of Rb1-mediated silencing of cell cycle genes and conferred resistance to CDK4/6 inhibitors [31]. Another histone modification regulated by $\mathrm{Rb} 1$ is methylation. $\mathrm{Rb} 1$ binds to the lysine methyl transferase SUV39H [32]. Rb1-mediated recruitment of SUV39H to the E2F1-target promoters leads to trimethylation of $\mathrm{H} 3 \mathrm{~K} 9$, creating a binding site for heterochromatin protein 1 (HP1), which triggers transcription silencing [32,33]. In addition to histone-modifying enzymes, $\mathrm{Rb} 1$ also recruits helicases Brm and Brg1, which are indispensable for the functionality of the SWI/SNF chromatin remodeling complex [34-36]. As a result of this recruitment, chromatin is packed more tightly, which adds another layer of transcriptional repression of E2F1-targeted genes and causes inhibition of cell cycle progression [37]. Finally, repression of E2F1-stimulated transcription can be mediated by Rb1-dependent recruitment of DNA methyltransferase 1 (DNMT1). DNMT1 recruitment is dependent on the amino-terminal part of DNMT1 (amino acids 416-913) and the intact pocket domain of Rb1 [38] (Figure 1B).

An interesting expansion of the $\mathrm{Rb} 1$ function is the regulation of silencing of repetitive DNA sequences, such as endogenous retroviruses or LINE-1 elements. These elements bind E2F1, which results in cell cycle-independent recruitment of Rb1. Epigenetic silencing of these elements is dependent on $\mathrm{H} 3 \mathrm{~K} 27$ trimethylation and it is markedly reduced in cells where $\mathrm{Rb} 1$ recruitment is impaired. The underlying mechanism is Rb1-dependent recruitment of EZH2 to the repetitive elements. Moreover, E2F1 binding-deficient Rb1 was still able to associate with $\mathrm{EZH} 2$, however, there was no deposition of methylation to the repetitive sequences, which confirms that maintenance of epigenetic silencing of the repetitive sequence is dependent on the formation of the E2F1-Rb1-EZH2 tricomplex [39].

The interaction of $\mathrm{Rb} 1$ with $\mathrm{E} 2 \mathrm{~F}$ is regulated by either post-translational modification of $\mathrm{Rb} 1$, which is discussed in the next section, or by binding with certain cellular and viral proteins. Among the latter, viral proteins, such as adenovirus (Ad) E1A, human papillomavirus (HPV) E7, and simian virus 40 (SV40) large T antigen (LTa), have been characterized in most detail [40]. Although diverse, these small viral proteins share a common $\mathrm{LxCxE}$ sequence that binds to the pocket domain of $\mathrm{Rb}$ [41-44]. Evidence indicates two general mechanisms by which these small viral proteins relieve the inhibition of $\mathrm{Rb} 1$ transcription. Initially, it was proposed that these viral proteins competed for the binding surface that interacts with E2F, thus interfering with the formation of the Rb1-E2F inhibitory complex [40]. However, later structural and functional studies revealed that another plausible mechanism is that these viral proteins interfere with the binding of $\mathrm{Rb} 1$ with HDACs through competition for the same docking site, namely the LxCxE binding cleft $[29,45]$. This interference results in the inactivation of the $\mathrm{Rb} 1$ function and failure to repress E2F transcription because of high histone acetylation and an open, permissive state of chromatin [46,47]. 
In addition to E2F1, Rb1 can bind other members of the E2F family, thereby adding further complexity to the role of this protein. E2F2, E2F3, E2F4 and E2F5 members contain $\mathrm{Rb} 1$-binding domains similar to E2F1 and interact with $\mathrm{Rb} 1[48,49]$. The interaction of $\mathrm{Rb} 1$ with E2F2 and E2F3 results in blockage of their pro-proliferative function, which is consistent with their established role as transcriptional activators $[48,50]$. However, E2F4 and E2F5 are considered transcriptional repressors and therefore the function of their interaction with $\mathrm{Rb} 1$ is different. The Rb1-E2F4/5 interaction occurs mainly in the G0 phase, where the two proteins form an inhibitory complex on the E2F1/2/3-promotors to block E2F1/2/3-stimulated transcription and maintain cell quiescence [51]. Indeed, it was shown that the main function of $\mathrm{E} 2 \mathrm{~F} 4 / 5$ is to regulate the development and terminal differentiation of various cell types [52-54].

\subsection{E2F-Independent Signaling}

The mechanism by which $\mathrm{Rb} 1$ regulates E2F-mediated transcription has been extensively studied; however, $\mathrm{Rb} 1$ binds to multiple other cellular proteins and alters their function independently of E2F, thereby affecting cell cycle progression, differentiation and transcription.

The E2F-independent role of $\mathrm{Rb} 1$ is well established in the context of lineage commitment and terminal differentiation of different cell types. $\mathrm{Rb} 1$ interacts with several transcription factors, such as MyoD, Runx2, C/EBP, NF-IL6, GATA1 and Pax8, and acts as a transcriptional co-activator. This interaction subsequently leads to stimulation of lineage-specific gene transcription and progenitor differentiation into mature tissue-specific cells, such as adipocytes, myocytes, hematopoietic cells and osteocytes [12-14,55-57]. The interaction between these transcription factors and $\mathrm{Rb} 1$ is mediated by the $\mathrm{LxCxE}$ sequence and $\mathrm{Rb} 1$ pocket domain, and mutation of this domain or overexpression of pocket domainbinding small viral proteins (E7, E1A) disrupt this interaction. The disruption of the interaction between $\mathrm{Rb} 1$ and these lineage-specific transcription factors results in impairment of differentiation, re-entry into the proliferative mode, and cancer development $[12,14,55]$. A complementary mechanism by which $\mathrm{Rb} 1$ stimulates terminal differentiation is by sequestering transcription factors that inhibit differentiation, such as EID-1 and ID2 (inhibitors of myocytes and osteocytes differentiation, respectively) [58,59] (Figure 1B).

Another important transcription factor bound by $\mathrm{Rb} 1$ is p65; however, there is no definitive consensus on the nature of this interaction. An initial study conducted on osteosarcoma cells showed that $\mathrm{Rb} 1$ binds and stimulates transcriptional activity of p65, which leads to an increased expression of cyclin D1 [60]. On the other hand, a more recent study revealed that $\mathrm{Rb} 1$ binds $\mathrm{p} 65$ in response to CDK-mediated phosphorylation and inhibits its transcriptional activity specifically towards PD-L1, which confers cancer immune evasion. Moreover, the authors showed that this interaction is mediated through the $\mathrm{Rb}$ N-terminal domain and the CCMB domain of p65 [61]. Thus, as observed for E2F factors, in some cases the binding of $\mathrm{Rb} 1$ induces transcription while in anothers it represses transcription, thereby suggesting a gene context-dependent effect of $\mathrm{Rb} 1$.

Another process directly associated with transcription control is an epigenetic modification of chromatin. As described above, Rb1 can recruit chromatin-modifying enzymes to E2F-target gene promoters and thus alter E2F-stimulated transcription. However, some reports indicate that $\mathrm{Rb} 1$ facilitates the function of several histone modifiers also in an E2F-independent manner. One such enzyme is histone demethylase KDM5a (RBP2), which demethylates tri- and di-methylated H3K4 [60]. The interaction of Rb1 and KDM5a is mediated by the classical $\mathrm{LxCxE}$ - pocket domain-binding interface. This interaction is important for myocyte specification, thereby supporting the crucial role of $\mathrm{Rb} 1$ in differentiation [62]. In addition to local facilitation of chromatin reorganization, Rb1 plays a key role in global heterochromatin maintenance. In this regard, fibroblasts deficient in Rb1 expression or expressing $\mathrm{Rb} 1$ with a deletion in the LxCxE binding cleft show highly decondensed chromatin, even in the centromeric regions [63]. More specifically, impaired heterochromatin maintenance of these fibroblasts was associated with a decrease in H4K20 methylation. 
This histone mark is deposited by histone methyltransferase SUV420H, which directly interacts with $\mathrm{Rb}$, thus heterochromatin dissolution is most probably a result of disruption of the Rb1-SUV420H interaction [64].

In addition to the $\mathrm{CDK}-\mathrm{Rb} 1-\mathrm{E} 2 \mathrm{~F}$ axis, $\mathrm{Rb} 1$ regulates cell cycle progression via several E2F-independent mechanisms. One such mechanism is the interaction with ubiquitin ligase complexes SCF and APC/C, which facilitate the transition between phases of the cell cycle $[65,66]$. Rb1 binds to both types of complexes and regulates the stability of the CDK inhibitor p27Kip1 via two distinct mechanisms. The SCF (SKP1-Cullin-F box) complex is a crucial regulator of the G1 phase transition and, when active, degrades cell cycle inhibitors, such as p21, p27 and p57 [66]. SKP2 is a crucial component of this complex, and it was shown to interact with the C-terminal part of $\mathrm{Rb} 1$. The sequestration of SKP2 by Rb1 leads to the release of $\mathrm{p} 27$ from the $\mathrm{SCF}^{\mathrm{Skp} 2}$ ubiquitination complex and its stabilization. Increased levels of p27 subsequently result in the inhibition of CDK activity and cell cycle arrest [67]. The APC/C complex is another multisubunit ubiquitin ligase that is active from the onset of mitosis through to the late G1 phase [65]. Rb1 interacts with the Cdh1 subunit of the APC/C complex simultaneously with SKP2. This bridging interaction then facilitates the ubiquitination of SKP2 by APC/C, which in turn leads to the stabilization of p27. The outlined series of events results in CDK inhibition and exit from the cell cycle $[68,69]$ (Figure 1B).

\section{The Role of Rb1 in Cancer Development and Progression}

Since the description of $\mathrm{Rb} 1$ as the first tumor suppressor protein, its genetic and epigenetic alteration and function have been extensively studied and characterized. As mentioned, its canonical function through its binding to E2F and transcriptional repression leads to the arrest of cell cycle progression. This inhibitory regulation is impaired in most types of cancer either through alteration of $\mathrm{Rb} 1$ expression (deletion, mutation, epigenetic silencing) or more often through functional inactivation by CDK-stimulated hyperphosphorylation. In addition to this canonical function, $\mathrm{Rb} 1$ is also important for the maintenance of genomic and chromosomal stability. These roles of $\mathrm{Rb} 1$ are addressed in the following sections.

\subsection{Genetic and Epigenetic Alteration of the Rb1 Locus}

Alteration in the gene locus coding for $\mathrm{Rb} 1$ protein is considered the first evidence showing the crucial role of tumor suppressor genes in cancer development. It was established very early that the homozygous deletion of $\mathrm{Rb} 1$ is the major genetic alteration driving the development of childhood retinoblastoma due to loss of Rb1 function as a cell cycle regulator [6,70]. Afterward, genetic alteration of the $R b 1$ locus was associated with the development of various types of cancer, including sarcoma, lung and ovarian cancer [71]. Analysis of mutation types and frequencies in patient-derived cancer samples deposited in the cBio Cancer Genomics Portal (cbioportal.org; accessed on 8 February 2022) database revealed that $R b 1$ is altered (point mutations, deletion, amplification) in $7 \%$ of all samples. However, mutational frequencies vary between tumor types, with bladder cancer and sarcoma samples having the highest proportion of Rb1 mutations (20-25\%), followed by prostate cancer, melanoma, and liver and brain cancer (10-15\%). Most of these mutations (88\%) are classified as driver mutations, which result in the absence of functional $\mathrm{Rb} 1$ protein ( $\mathrm{Bb} 1$ locus deletion-41\%; Rb1 truncating mutation present-33\%, $\mathrm{Rb} 1$ splice variant mutation present-12\%). These frequencies are consistent with $\mathrm{Rb} 1$ being a negative regulator of the cell cycle. Moreover, $16 \%$ of the alterations are missense mutations (Figure 2). These are distributed throughout the whole gene with no apparent recurrent mutations in either of the residues or domains $[15,16]$. The significance of these point mutations is unclear, and only a few of them have been studied. For example, mutations Leu607Ile, Arg698Trp, and Arg621Cys identified in breast cancer patients were shown to have impaired pro-apoptotic function of $\mathrm{Rb} 1$ and they stimulated resistance to 5-FU/mitomycin or doxorubicin [72]. Interestingly, different Rb1 mutations were identified as a result of the treatment of breast cancer patients with CDK inhibitors and were 
considered to confer therapeutic resistance $[73,74]$. Moreover, the association of these mutations with the clinical outcome of patients with cancer is not well established, thus further complicating the role of $\mathrm{Rb} 1$ in cancer. However, mutations in upstream regulators of $\mathrm{Rb} 1$ (cyclins, CDKs or CDKis) are more prevalent and are associated with a strong and clear clinical outcome, namely worse prognosis and shorter survival [75-78].

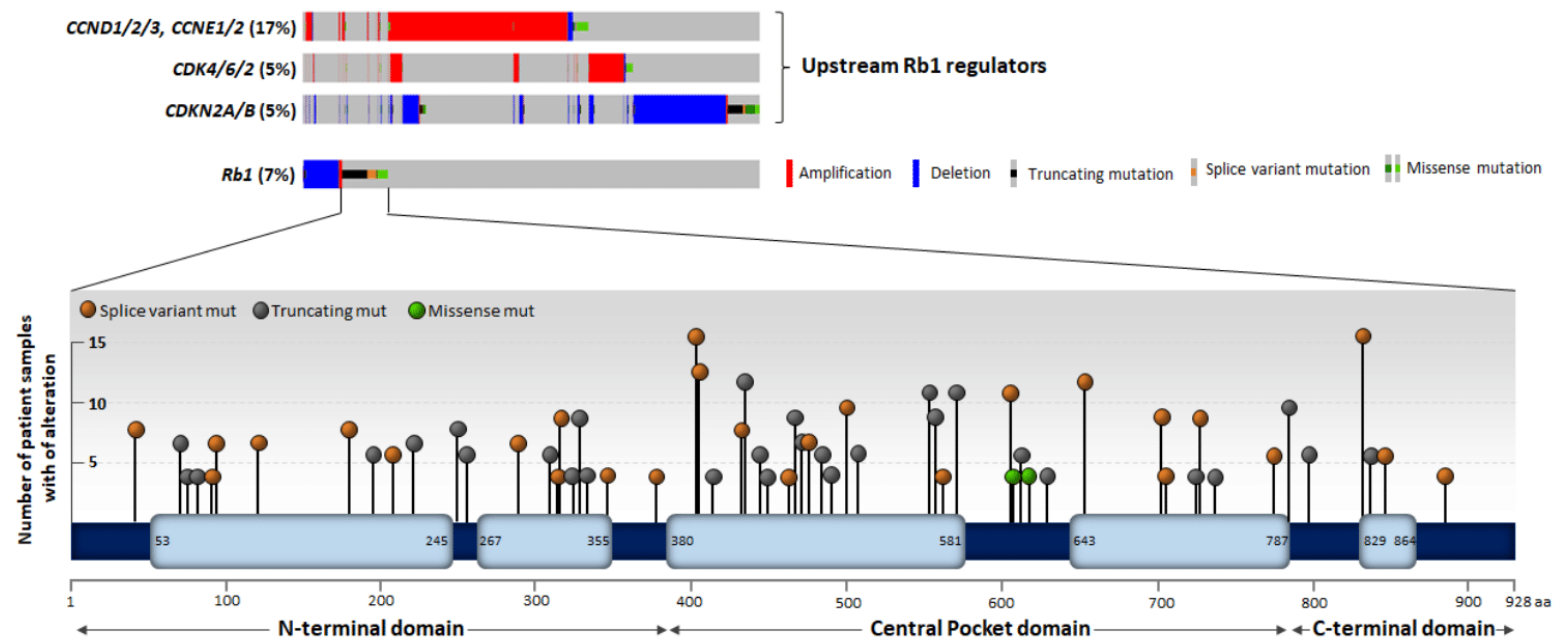

Figure 2. $\mathrm{Rb} 1$ axis gene alteration in cancer. The major constituents of the $\mathrm{Rb} 1$ signaling axis (Cyclins, CDKs, CKIs, Rb1) are significantly altered in human cancers. Major upstream alterations are Cyclin and $C D K$ gene amplification and $C D K N 2 A / B$ deletion, which results in hyperactivation of $C D K$ and functional inactivation of $\mathrm{Rb} 1$. Moreover, $R b 1$ is altered in around $7 \%$ of tumors across different types of cancer. Roughly half of the alterations are $R b 1$ deletion and the other half are point mutations. The latter is distributed throughout the whole gene with no apparent hotspots. Of note, the vast majority of these mutations are truncations or splice variant mutations, but not substitutions, which would result in expression of an $\mathrm{Rb} 1$ protein lacking certain regions.

Another common mechanism for the downregulation of Rb1 expression is hypermethylation of its promoter region. This methylation was first described in retinoblastoma patients, and in vitro experiments confirmed that $R b 1$ contains a $\mathrm{CpG}$ island, which, when methylated, strongly reduces Rb1 expression [79]. Mechanistically, methylation abolishes the binding of activating transcription factor (ATF)-like factor and retinoblastoma-binding factor 1 (RBF1) to their cognate sequences [80]. Subsequent methylation-specific screening efforts revealed $\mathrm{Rb}$ promoter hypermethylation in $20-25 \%$ of brain tumors and $11 \%$ of retinoblastomas [81-83].

\subsection{Canonical Tumor Suppressor Role of Rb1}

However, the phosphorylation of Rb1 by CDKs is the most common event for Rb1 inactivation. Phosphorylation by CDKs serves to dissociate the binding of Rb1 to E2F (Figure 1). Correspondingly, oncogenic activation of CDK4/ 6 either by activating mutations in CDK4/6, gene amplification of positive regulators such as CCND1, or deletion of CDK4/6 inhibitors such as $\mathrm{p} 16$, results in functional inactivation of $\mathrm{Rb} 1$ protein and the expression of genes that are important for mitosis and cell cycle progression [84-88] (Figure 2). In line with this evidence, clinically approved CDK4/6 inhibitors (e.g., Palbociclib, Ribociclib, Abemaciclib) significantly impair tumor cell proliferation, especially in ER+ breast cancer [89,90]. This inhibitory effect is almost exclusively dependent on the presence of $\mathrm{Rb} 1$ protein [91,92]. The clinical efficacy of CDK4/6 inhibitors is highly positively correlated with the expression of $\mathrm{Rb} 1$, and the loss of functional $\mathrm{Rb} 1$ protein through locus deletion or point mutations is a common mechanism of acquired resistance to CDK4/6 inhibitors [74,93]. However, other signaling alterations can lead to CDK4/6 inhibitor resistance. Among these, the upregulation of Cyclin D expression or amplification of Cyclin E is clinically relevant and 
leads to the inactivation of $\mathrm{Rb} 1$ [75,94-97]. This absolute requirement of $\mathrm{Rb} 1$ inactivation for successful cell cycle progression offers a therapeutic opportunity to develop compounds to directly stimulate the Rb1 function by increasing its binding to its partners, therefore maintaining a more sustainable and stronger cell cycle exit.

Another mechanism by which $\mathrm{Rb} 1$ protects cells from malignant transformation is through the maintenance of proficient DNA damage repair and chromosomal stability. Several studies report the involvement of $\mathrm{Rb} 1$ protein in DNA double-strand break (DSB) repair by all three major DSB repair pathways-homologous recombination (HR), nonhomologous end joining (NHEJ), and microhomology-mediated end joining (MMEJ). Rb1 localizes to the sites of DNA damage in an E2F1- and ATM (serine-threonine kinase ataxiatelangiectasia mutated)-dependent manner. Mechanistically, ATM-phosphorylates E2F1 at $\mathrm{S} 29$, which leads to its recruitment to $\mathrm{p}-\gamma \mathrm{H} 2 \mathrm{AX}$ foci. $\mathrm{Rb} 1$ is localized to these foci via association with E2F1, and Brg1 DNA helicase is subsequently recruited in an Rb1-dependent fashion [98]. Recruitment of Brg1 results in nucleosome repositioning, allowing proper DSB repair to take place [99]. Rb1 also stimulates DSB repair by promoting end resection and the HR and NHEJ repair pathways. Rb1 colocalizes with CtIP (DNA endonuclease RBBP8) at the sites of DNA damage and stimulates CtIP phosphorylation on T847, CtIP loci formation, and RPA (Replication Protein A) loading [100]. These events subsequently result in DNA break repair [101]. Moreover, by interacting with key components of NHEJ (XRCC5 and XRCC6), Rb1 is directly involved in the stimulation of NHEJ repair [102]. Taken together, these studies show that Rb1-deficient cells are hypersensitive to DNA damage agents, and this feature may be useful for designing therapeutic strategies based on synthetic lethality.

In addition to its direct role in the DSB repair, Rb1 also facilitates genome integrity through stabilizing heterochromatin. As described earlier, $\mathrm{Rb} 1$ interacts with and recruits several epigenetic factors that alter chromatin structure. It is now well established that $\mathrm{Rb} 1$ plays a crucial role in stabilizing heterochromatin at centromeric and telomeric regions through maintenance of sufficient levels of H4K20 methylation. Rb1-deficient mouse fibroblasts or fibroblasts expressing $\mathrm{Rb} 1$ mutated in the LxCxE binding cleft show decondensed chromatin and decreased H4K20 levels specifically at telomeres and pericentric chromatin $[63,64]$. This effect is independent of E2F1 and is most probably facilitated by the recruitment of Suv420h1/2, which is a known methyltransferase for H4K20. Moreover, this aberrant H4K20 methylation is associated with impaired HP1 (Heterochromatin Protein 1), which is crucial for heterochromatin stabilization at telomeres and pericentric regions [103]. In addition to stabilizing heterochromatin, several reports established a clear connection between $\mathrm{Rb} 1$ and Cohesin II recruitment. $R b 1$ dosage is strongly associated with the protection of cells from chromosomal alterations and aneuploidy. Full Rb1 deletion leads to a high rate of chromosomal instability, and even deletion of a single copy has a profound effect. Mechanistically, Rb1 recruits Cohesin II to the centromeric regions and thus promotes faithful segregation of sister chromatids [104,105]. In conclusion, besides its well-established role in regulating G1/S progression, $\mathrm{Rb} 1$ is relevant for the maintenance of chromosomal stability throughout the whole cell cycle, including mitosis. Abolishing $\mathrm{Rb} 1$ functionality thus leads to chromosomal instability (CIN), which further fuels cancer progression [106-108].

\subsection{Non-Canonical Function of Rb1}

Finally, yet importantly, some functions of Rb1 can be appreciated only in the context of the cancer microenvironment and interaction with immune cells. Several reports demonstrate the involvement of the $\mathrm{E} 2 \mathrm{~F} 1 / \mathrm{Rb} 1$ axis in the regulation of antitumor immune response. Most of these focused on the outcome of systemic CDK4/6 inhibition, which was evaluated mainly as the effect on immune cell proliferation and recruitment [109-112]. However, the role of $\mathrm{Rb} 1$ in modulating intrinsic tumor immunogenicity has not been thoroughly addressed. As described above, $\mathrm{Rb} 1$ inactivation triggers increased genomic instability $[104,113,114]$, which can subsequently lead to the generation of proteins with altered sequences that can serve as tumor-associated or tumor-specific antigens, which 
would be presented on the surface of cancer cells [115]. These neoantigens could then stimulate immune cell recruitment and activation, thus leading to cytotoxicity-mediated cell death [116]. Indeed, tumors with a higher mutagenic burden produce greater amounts of tumor neoantigens [117-119]. Such immunologically hot tumors are characterized by a higher number of infiltrating lymphocytes and better clinical efficacy of therapy targeting immune checkpoint inhibitors, such as PD/PD-L1 or CTLA4 [120-122].

Similarly, and as mentioned above, it was shown that $\mathrm{Rb} 1$ participates in regulating PD-L1 expression; however, this function is paradoxical. A recent study revealed that CDK4/6-mediated phosphorylation of Rb1 on residues S249 and T252 increases its affinity to p65 and inhibits its transcriptional activity. Since one of the p65 targets is PD-L1, this inhibition leads to decreased PD-L1 expression and subsequent impairment of immune evasion [61].

Moreover, $\mathrm{Rb} 1$ binds to EZH2 and alters the epigenetic modification status of certain sequences [39]. Such inhibitory complexes can be formed on the promoters of certain surface ligands that are important for immune cell recruitment. Indeed, there is substantial evidence that epigenetic modifiers such as EZH2 play a crucial role in regulating this process (see review [123]).

\section{Upstream Regulation and Post-Translational Modifications}

Given that $\mathrm{Rb} 1$ was described as a prototypical tumor suppressor more than 40 years ago, there is a huge amount of evidence regarding its post-translational modifications. According to phosphositeplus.org, there are 105 modified residues in Rb1. Phosphorylation (61 residues) and ubiquitination (29 residues) are the most common modifications of this protein, while others (acetylation, methylation) have received less attention. The following chapter describes these post-translational modifications, along with the upstream signaling and downstream significance (Figure 3, Table 1).

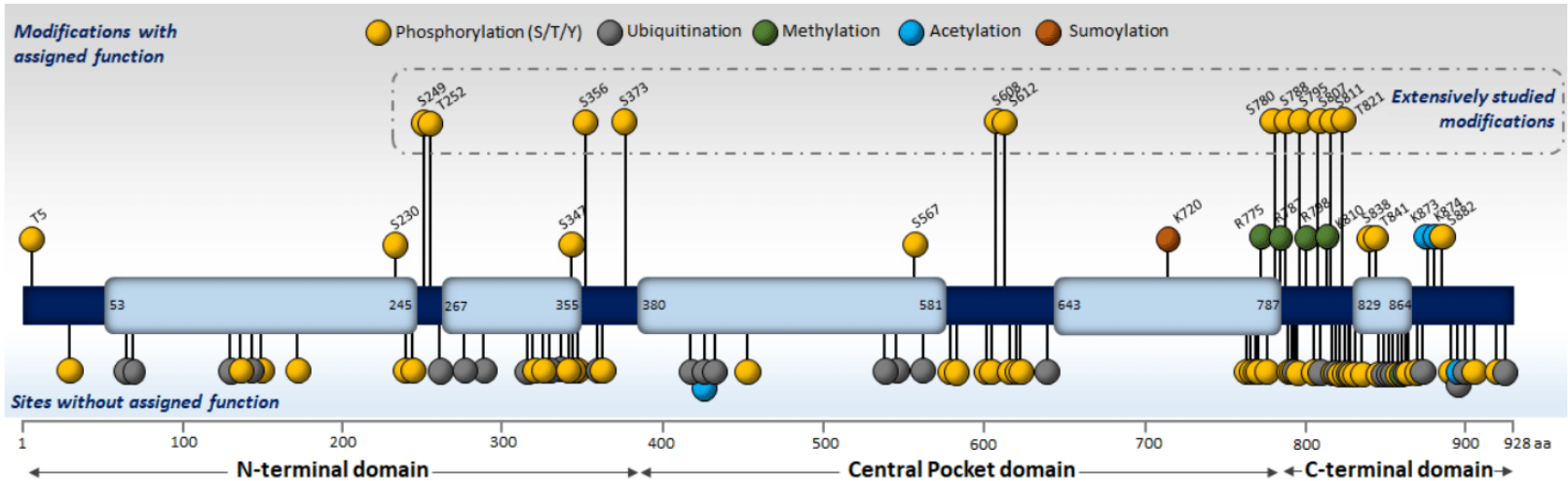

Figure 3. $\mathrm{Rb} 1$ post-translational modification. To date, 105 residues on $\mathrm{Rb} 1$ protein have been shown to be post-translationally modified. Roughly a quarter of these modifications (upper part) have assigned functions, and 12 of them (all phosphorylations) have been extensively studied (S249, T252, S356, S373, S608, S612, S780, S788, S795, S807, S811, T821).

Table 1. Rb1 post-translational modifications and their role in regulating cellular signaling.

\begin{tabular}{ccccc}
\hline Site & Modification & Modifier & Molecular Function & Outcome \\
\hline T5 & Phosphorylation & N.A. & N.A. & Apoptosis inhibition \\
S230 & Phosphorylation & N.A. & N.A. & Apoptosis inhibition \\
S249 & Phosphorylation & p38 $\alpha$ & Increase affinity to E2F1 & Cell cycle inhibition \\
& & CDK1/2 & Reduce affinity to HDAC5 & Transcription regulation \\
T252 & Phosphorylation & p38 $\alpha$ & and EID1 & [124] \\
& & CDK1/2 & Reduce affinity to HDAC5 & Cell cycle inhibition \\
& & & and EID1 & Transcription regulation \\
\hline
\end{tabular}


Table 1. Cont.

\begin{tabular}{|c|c|c|c|c|c|}
\hline Site & Modification & Modifier & Molecular Function & Outcome & Reference \\
\hline S347 & Phosphorylation & $\mathrm{N} / \mathrm{A}$ & Promote caspase cleavage & $\begin{array}{l}\text { Increased } \mathrm{Rb} \text { proteolysis } \\
\text { during apoptosis }\end{array}$ & [127] \\
\hline T356 & Phosphorylation & CDK2 & Reduce affinity to E2F1 & Cell cycle entry & {$[124,128]$} \\
\hline T373 & Phosphorylation & CDKs & Reduce affinity to E2F1 & Cell cycle entry & [128] \\
\hline S567 & Phosphorylation & p38 $\alpha$ & Increase affinity to HDM2 & $\mathrm{Rb}$ degradation and apoptosis & {$[129,130]$} \\
\hline S608 & Phosphorylation & CDK2 & Reduce affinity to E2F1 & Cell cycle entry & {$[128,131,132]$} \\
\hline \multirow[t]{2}{*}{ S612 } & Phosphorylation & CDK2 & Reduce affinity to E2F1 & Cell cycle entry & [128] \\
\hline & & $\begin{array}{l}\text { Chk1/ } \\
\text { Chk2 }\end{array}$ & Increase affinity to E2F1 & $\begin{array}{c}\text { Cell survival upon DNA } \\
\text { damage }\end{array}$ & {$[133]$} \\
\hline K720 & Sumoylation & $\mathrm{N} / \mathrm{A}$ & Reduce affinity to E2F1 & Cell cycle entry & {$[134,135]$} \\
\hline R775 & Methylation & PRMT4 & Reduce affinity to E2F1 & Cell cycle entry & [136] \\
\hline \multirow[t]{3}{*}{ S780 } & Phosphorylation & CDK4 & Reduce affinity to E2F1 & Cell cycle entry & [137] \\
\hline & & Aurora B & Increase affinity to E2F1 & Prevents endoreduplication & [138] \\
\hline & & TG2 & Reduce affinity to E2F1 & Cell cycle entry & [139] \\
\hline R787 & Methylation & PRMT4 & Reduce affinity to E2F1 & Cell cycle entry & [136] \\
\hline S788 & Phosphorylation & CDKs & Reduce affinity to E2F1 & Cell cycle entry & [23] \\
\hline S795 & Phosphorylation & CDK4 & Reduce affinity to E2F1 & Cell cycle entry & [23] \\
\hline R798 & Methylation & PRMT4 & Reduce affinity to E2F1 & Cell cycle entry & [136] \\
\hline Y805 & Phosphorylation & Abl tyrosine kinase & N.A. & $\begin{array}{l}\text { Necessary for survival of } \\
\text { Abl-dependent tumor cells }\end{array}$ & [140] \\
\hline S807 & Phosphorylation & CDKs & Reduce affinity to E2F1 & Cell cycle entry & [131] \\
\hline K810 & Methylation & Set7 /9 Smyd2 & $\begin{array}{l}\text { Inhibits Cdk-directed } \\
\text { phosphorylation }\end{array}$ & Cell cycle arrest & {$[141,142]$} \\
\hline S811 & Phosphorylation & CDKs & Reduce affinity to E2F1 & Cell cycle entry & {$[131,143]$} \\
\hline \multirow[t]{2}{*}{ T821 } & Phosphorylation & CDK2 & Reduce affinity to E2F1 & Cell cycle entry & [23] \\
\hline & & & Reduce affinity to HDAC5 & & [31] \\
\hline T826 & Phosphorylation & CDKs & Reduce affinity to E2F1 & Cell cycle entry & [23] \\
\hline S838 & Phosphorylation & p38 $\alpha$ & $\begin{array}{l}\text { Disrupts condensin II } \\
\text { interaction with chromatin }\end{array}$ & Chromatin decondensation & {$[144,145]$} \\
\hline T841 & Phosphorylation & p38 2 & $\begin{array}{l}\text { Disrupts condensin II } \\
\text { interaction with chromatin }\end{array}$ & Chromatin decondensation & {$[144,146]$} \\
\hline K873 & Acetylation & $\mathrm{N} / \mathrm{A}$ & $\begin{array}{c}\text { Increase affinity to MDM2 } \\
\text { Reduce affinity to E2F1 }\end{array}$ & $\begin{array}{l}\text { Cell cycle exit and } \\
\text { cell differentiation }\end{array}$ & {$[147,148]$} \\
\hline K874 & Acetylation & $\mathrm{N} / \mathrm{A}$ & Increase affinity to MDM2 & $\begin{array}{l}\text { Cell cycle exit and } \\
\text { cell differentiation }\end{array}$ & {$[147,148]$} \\
\hline S882 & Phosphorylation & N.A. & Promote caspase cleavage & Increased $\mathrm{Rb}$ proteolysis & {$[127,147]$} \\
\hline \multicolumn{6}{|c|}{ Rb modification without assigned function (identified through HTP proteomics) } \\
\hline S350 & Phosphorylation & & & & [145] \\
\hline T353 & Phosphorylation & & & & [149-151] \\
\hline S624 & Phosphorylation & & & & [145] \\
\hline T774 & Phosphorylation & & & & [152] \\
\hline T778 & Phosphorylation & & & & {$[145,152]$} \\
\hline Y790 & Phosphorylation & & & & {$[152,153]$} \\
\hline Y813 & Phosphorylation & & & & [153] \\
\hline S816 & Phosphorylation & & & & [154-156] \\
\hline T823 & Phosphorylation & & & & {$[146,156,157]$} \\
\hline 855 & Phosphorylation & & & & {$[145,158,159]$} \\
\hline
\end{tabular}

\subsection{Phosphorylation}

The prototypical and most widely studied post-translational modification of $\mathrm{Rb} 1$ is phosphorylation. It was the first modification identified to be crucially important for Rb1 function as a tumor suppressor [160]. To date, 61 residues (serine, threonine, tyrosine) have been shown to be phosphorylated by several kinases, such as Cyclin-dependent Kinases (CDKs), p38 and Aurora B kinase (AurKB) [94,125,129,161], 19225156. A textbook example of phosphorylation-related modulation of $\mathrm{Rb} 1$ function is the phosphorylation of serine and threonine residues in the C-terminal domain of the protein by CDKs. These phosphorylations lead to the inactivation of $\mathrm{Rb} 1$, disassociation of the E2F transcription factor, and the induction of transcription of genes regulating cell cycle entry and progression [161]. Proteomic and mutational analysis of the $\mathrm{Rb} 1$ residues revealed 16 putative CDK-targeted phosphorylation residues, of which 15 are located on the surface and are thus accessible to phosphorylation [162,163]. Although all of these sites can be phosphorylated by individual CDKs, the surrounding sequence plays an important role in specificity and selectivity. 
Mechanistically, it is generally accepted that cells in the G0 phase of the cell cycle do not contain phosphorylated $\mathrm{Rb} 1$ on any of the residues [164,165], although a degree of basal phosphorylation of these sites is constant, as shown by mass spectrometry analyses. However, as cells enter the cell cycle, the phosphorylation pattern becomes more complex, and it is even possible to talk about an Rb1 phosphorylation code [163]. Historically, it was shown that Rb1 is initially mono-phosphorylated at S249, T252, T356, S608, S788, S807, S811 and S826 by CDK4/ 6-Cyclin D throughout the G1 phase, thus priming it for further phosphorylation again by the same complex or by CDK2-Cyclin E at T5, T373 and S795 [166]. Moreover, it was also reported that phosphorylation of Rb1 on residues S807/811 by CDK3 is necessary for the G0-G1 transition [167]. Later, at the end of the G1 phase, the CDK2-Cyclin E complex phosphorylates S612 and T821, which results in fully hyperphosphorylated $\mathrm{Rb} 1$, which then dissociates from $\mathrm{E} 2 \mathrm{~F}$, thus allowing progression to the S phase [166].

Since E2F1 was considered the most important Rb1 interaction partner, the effect of phosphorylation of these residues on the Rb1-E2F1 interaction was studied mainly with a focus on the interaction with E2F1, leaving the possibility that some of the phosphorylations may be more relevant for alternative binding partners. Initially, it was reported that phosphorylation of S788 and S795 directly inhibits the binding of Rb1 to E2F1, whereas phosphorylation of T821 and T826 facilitates the closing of the Rb1 structure as a result of increased binding of its C-terminal and central pocket domain [23]. Furthermore, phosphorylation of T373 causes a structural change that increases intramolecular interaction between the $\mathrm{Rb} \mathrm{N}$-terminal and the pocket domain. Finally, phosphorylation of S608 results in the burying of the loop with CDK target sites within the Rb1 pocket domain, thus impairing hyperphosphorylation [168]. These findings were further corroborated by evidence that most CDK target sites on Rb1 are phosphorylated in the M-phase of the cell cycle $[157,169]$. However, this simplistic view of phosphorylation dynamics was challenged by a comprehensive analysis of the phosphorylation status of individual residues and their function. Narasimha and colleagues showed that $\mathrm{Rb} 1$ is exclusively monophosphorylated throughout the G1 phase and that Cyclin D-CDK4/ 6 complexes mediate this phosphorylation. Moreover, the study revealed that monophosphorylation can occur on any of the CDK-target sites, but always as a single event. At the restriction point, CDK2/Cyclin E complexes then hyperphosphorylate Rb1, thus allowing progression to S-phase [162]. These results were verified by a later study that showed that even single phosphorylation of $\mathrm{Rb} 1$ by $\mathrm{CDK} 6$ greatly reduces the capacity of $\mathrm{Rb} 1$ to further interact with Cyclin D/CDK6 complexes [163]. Interestingly, after DNA damage, Rb1 is monophosphorylated again by the action of the Cyclin D/CDK4/6 complex [162].

Since $\mathrm{Rb} 1$ is a major regulator of the cell cycle, it integrates signals from stress response pathways such as DNA damage and environmental stresses. It was shown that S612 is phosphorylated by Chk $1 / 2$ in response to DNA damage and that this phosphorylation increases its affinity towards E2F1 [133]. Similar to phosphorylation at S608, S612 phosphorylation could involve shielding of the loop containing hyperphosphorylation sites that increase the affinity to E2F1 [133]. However, the phosphorylation of these sites is highly context-specific because phosphorylation of S608/S612 together with T356/T373 leads to the disruption of $\mathrm{Rb} 1$ and E2F1 binding [128], again suggesting a complex code for Rb1 phosphorylation and regulation of its activity. An important function of Rb1 phosphorylation in sensing DNA damage is underlined by evidence showing that functional inactivation of $\mathrm{Rb} 1$ by deletion or mutation leads to increased sensitivity to DNA-damaging agents [170-172].

Furthermore, $\mathrm{Rb} 1$ is a direct target of the stress-activated kinase $\mathrm{p} 38 \alpha$, which integrates stress signaling beyond DNA damage. $\mathrm{p} 38 \alpha$ is a master regulator of stress signaling pathways [173] and, indeed, several studies report p38 $\alpha$-mediated Rb1 phosphorylation. An initial study indicated that $\mathrm{p} 38 \alpha$ stimulates phosphorylation of $\mathrm{Rb} 1$ at S807/811 after mitogenic stimuli such as serum addition. However, this phosphorylation seems to be indirect through stimulation of Cyclin D [174]. Stronger evidence showed that p38 $\alpha$ directly phosphorylates five residues on Rb1 (S249, T252, S576, S838, T841). Of note, Rb1 
is phosphorylated at S249/T252 by p38 $\alpha$ in response to environmental stress, such as osmostress, oxidative stress, and DNA damage $[125,175]$. Additionally, induction of TGF $\beta$ RII in metastatic prostate cancer cells mediates RB S249/T252 phosphorylation by p38 which prevents bone metastasis [176]. A study analyzing the global change of phosphorylation after $\mathrm{NaCl}$-induced stress showed increased phosphorylation of these residues [177]. In contrast to the phosphorylation by CDKs, S249/T252 phosphorylation increases interaction between $\mathrm{Rb} 1$ and $\mathrm{E} 2 \mathrm{~F} 1$, thus causing cell cycle arrest. An Rb1 mutant that cannot be phosphorylated by p38 $\alpha$ on those sites is deficient in cell cycle delay upon stress, and cells show a clear reduction in viability. Of note, the increased affinity of E2F-Rb1 due to S249/T252 phosphorylation is also observed in the presence of high CDK activity. Thus, this phosphorylation can override the phosphorylation in central and pocket domains of $\mathrm{Rb} 1$ by CDKs that favor Rb1/E2F1 disassociation, thus representing a higher regulatory level to stop the cell cycle in unfavorable environmental conditions [125]. Of note, cells expressing a mutant carrying a phosphomimetic mutation on those sites show reduced tumorigenesis in vitro and in vivo [125].

In addition to $\mathrm{p} 38 \alpha$, other reports showed that S249/T252 can be also phosphorylated by CDKs, which results in altered binding with other Rb1 interaction partners such as p65 and HDAC5 [31,61]. This particular case further highlights the complexity of Rb1 regulation, which appears to be context-dependent and to be influenced by the concomitant phosphorylation of other residues of $\mathrm{Rb} 1$, affecting the overall outcome of single phosphorylation in each case. Indeed, a recent study analyzing the role of monophosphorylated $\mathrm{Rb} 1$ showed that distinct monophosphorylation leads to different signaling outcomes [163].

Another well-described p38 $\alpha$-directed Rb1 phosphorylation site is S567. This phosphorylation is triggered by DNA damage and it results in the disassociation of Rb1 from E2F1, increased interaction with HDM2 ubiquitin ligase, Rb1 poly-ubiquitination and subsequent targeting to proteasomal degradation $[129,130]$. This signaling requires additional regulatory circuits that block the cell cycle-promoting function of released E2F1 but allow the stimulation of apoptosis [20,178]. This observation highlights that there might be $\mathrm{Rb} 1$ fractions with different phosphorylation patterns depending on the promoter regions (cell cycle vs. apoptotic) in which these particular Rb1/E2F1 complexes are located. The most recently identified p38 $\alpha$-targeted phosphorylation sites are S838 and S841 [144]. This particular phosphorylation was studied in immune cells in response to T-cell receptor activation. p38 $\alpha$-mediated $\mathrm{Rb} 1$ phosphorylation of these sites results in disruption of $\mathrm{Rb} 1$ and Condensin II association and subsequent chromatin relaxation. However, the overall significance of this phosphorylation is not clear, since it was also identified as a target of Aurora kinase in cell types of non-immune origin [150].

Of note, the isoform p38 $\gamma$ cooperates with CDKs, regulating entry into the cell cycle. In mouse hepatocytes, $\mathrm{p} 38 \gamma$ induces proliferation after partial hepatectomy by promoting the phosphorylation of $\mathrm{Rb} 1$ at known CDK target residues. Lack of $\mathrm{p} 38 \gamma$ or treatment with the $\mathrm{p} 38 \gamma$ inhibitor protects against the chemically induced formation of liver tumors [179].

$\mathrm{Rb} 1$ is directly phosphorylated by the mitotic kinase Aurora B at S780. This phosphorylation is important for mediating the role of Aurora B in regulating the postmitotic duplication checkpoint, thus protecting the cells from aneuploidy [138]. These results are well aligned with the $\mathrm{Rb} 1$ function in protecting genome integrity discussed above. Interestingly, the deletion of $\mathrm{Rb} 1$ is synthetically lethal with deletion/inhibition of both Aurora A and B kinases [180-182].

In contrast to $\mathrm{Rb} 1$ phosphorylation, very little is known about the dephosphorylation of this protein. Two major phosphatases, namely PP1 and PP2A, were described for Rb1 dephosphorylation [183]. Although both phosphatases can dephosphorylate Rb1 in vitro and in vivo, the functional relevance and upstream activation of them over Rb1 differs. Several reports identified PP1 as a major Rb1 phosphatase during cell cycle progression and mitotic exit [184,185]. Moreover, constitutively active PP1 arrests cells in the G1 phase and this effect is dependent on Rb1 [186]. Rb1 binds to PP1 through its C-terminal part and the binding is not dependent on the Rb1 phosphorylation level because both 
hypophosphorylated and hyperphosphorylated Rb1 can interact with this phosphatase. However, the phosphorylation of certain residues, such as S249, T373, S788, S795, T811, T821 and T826, can negatively affect the interaction of PP1 with Rb1 $[187,188]$. Moreover, similarly to the ordered fashion of Rb1 phosphorylation, dephosphorylation by PP1 is also sequential and temporally regulated $[189,190]$. This spatiotemporal regulation of $\mathrm{Rb} 1$ dephosphorylation can arise from the different affinities of PP1 isoforms or the presence or absence of different PP1 regulatory subunits [191,192]. For example, two regulatory PP1 subunits, MYPT and SPN, play a role in a tumor suppressor that is mediated by stimulating Rb1 dephosphorylation [191,193].

A second phosphatase involved in mediating Rb1 dephosphorylation is PP2A. Two complementary mechanisms of action were proposed for this phosphatase role. On the one hand, PP2A dephosphorylates CDKs, thereby resulting in lower phosphorylation activity towards $\mathrm{Rb} 1$. This mechanism is present mainly in normally cycling, unchallenged cells [194]. On the other hand, it was shown that the major role of PP2A in the regulation of $\mathrm{Rb} 1$ phosphorylation is through its direct dephosphorylation as a response to cellular stress, such as DNA damage, ionizing radiation and oxidative stress [195-197]. However, this dephosphorylation seems to be a swift event affecting global Rb1 phosphorylation and, unlike PP1 it is not sequential or site-specific.

\subsection{Acetylation, Methylation and Sumoylation}

In addition to phosphorylation, various other post-translational modifications, namely acetylation, methylation and sumoylation, modulate Rb1 function. Several high throughput proteomic studies identified six acetylated lysine residues on the Rb1 protein [198,199]. However, acetylation of only two of the lysines (K873/874) was studied and functionally annotated. These residues are located in the C-terminal pocket domain of Rb1, in the vicinity of major CDK-directed phosphorylation sites, thus their acetylation was expected to alter $\mathrm{Rb} 1$ function. Indeed, acetylation of K873/874 by p300/CBP or by P/CAF impairs $\mathrm{Rb} 1$ phosphorylation by CDKs and, also, increases Rb1 binding to the ubiquitin ligase MDM2 (Mouse double minute 2 homolog) [199]. This acetylation was present mostly in the terminally differentiated cells, which implies that acetylation is a more stable way to achieve the cell cycle arrest necessary for cellular differentiation [148]. Moreover, it was shown that DNA damage stimulates the acetylation of $\mathrm{Rb} 1$, which would result in disassociation of the Rb1-E2F1 complex [147]. However, additional layers of regulation are needed as the interaction of Rb1 with E2F1 on apoptotic genes is important for survival upon DNA damage $[20,200,201]$.

Similar to acetylation, lysine and arginine methylation also affect the functionality of $\mathrm{Rb} 1$. The most studied site of methylation is K810. This conserved residue lies next to an important CDK phosphorylation site, S807/811, thus implying functional interaction between these post-translational modifications. K810 is methylated by the methyltransferase Set7/9 and this methylation prevents CDK binding and subsequent Rb1 phosphorylation. Moreover, this methylation is stimulated after DNA damage and it appears to play a crucial role in cell cycle arrest upon DNA damage, by two mechanisms. The first would be the promotion of canonical binding to E2F1, followed by recruitment of HP1 and repression of cell cycle-promoting genes [141]. The second mechanism would be the recruitment of 53BP1 (p53 binding protein 1), which is stimulated directly by Rb1 methylation, thus triggering DNA damage repair [202]. Interestingly, on the other hand, arginine methylation stimulated by PRMT4 on Rb1 R775, R787, and R798 has opposite effects. Arginine methylation of $\mathrm{Rb} 1$ is required for full phosphorylation of $\mathrm{Rb} 1$ by CDKs, disassociation from E2F1, and efficient cell cycle progression [141].

Finally, Rb1 can be also subjected to SUMOylation. This post-translational modification is blocked by interaction with small viral proteins; however, the significance of this modification has not been addressed in depth [134,135]. 


\section{Concluding Remarks}

$\mathrm{Rb} 1$ is a multifunctional protein that integrates signals from multiple upstream events and plays important roles beyond the regulation of the cell cycle. $\mathrm{Rb} 1$ is extensively modified by phosphorylation, acetylation and methylation. Although the interplay between the qualitative and quantitative extent of these modifications is only now starting to be uncovered, a highly complex regulation of the $\mathrm{Rb} 1$ function is emerging. It is becoming clear that the modification of the same residue can result in different outcomes depending on other modifications present, and that there are pools or subpopulations of Rb1 molecules that are differentially modified and play different roles. It could be postulated that the downstream functional output of $\mathrm{Rb} 1$ is regulated by a "post-translational modification code". This mechanism of action can be illustrated by the differential output of Rb1-E2F1 interaction in cycling cells and cells undergoing DNA damage. Blocking Rb1 hyperphosphorylation, which would lead to the increased interaction of $\mathrm{Rb} 1$ and $\mathrm{E} 2 \mathrm{~F} 1$, is a favorable outcome on the promoters of cell cycle genes, but it is unfavorable at the pro-apoptotic gene promoters and could lead to insensitivity to DNA damage. Thus, deciphering the "post-translational modification code" of Rb1 might prove crucial to decouple these two signaling events. Moreover, it was shown that some modifications are dominant over others and that they determine the overall output independently of the other ones present.

The importance of the Rb1-E2F signaling axis in cancer is well recognized, however, the only clinically approved drugs targeting the pathway are CDK inhibitors. The efficacy of these inhibitors is dependent on the Rb1 status, thus they cannot be used for patients with non-functional Rb1 protein (deletion, promoter hypermethylation, inactivating mutations) [93]. On the other hand, Rb1 deficiency offers therapeutic opportunities associated with higher sensitivity of such tumors to DNA damaging therapy or microtubule drugs. For example, breast cancer patients with $\mathrm{Rb}$ loss exhibited better clinical responses to radiotherapy and systemic chemotherapy $[170,172,203,204]$.

In summary, the crucial role of $\mathrm{Rb} 1$ in cell cycle regulation calls for a deeper understanding of its modifications, which in turn would contribute to the design of targeted compounds of therapeutic interest.

Author Contributions: Conceptualization, E.d.N., F.P., A.T.-S. and R.J;; writing-original draft prepara-tion, all authors.; writing-review and editing: E.d.N., F.P. and R.J. All authors have read and agreed to the published version of the manuscript.

Funding: This project received funding from the European Union's Horizon 2020 research and innovation program under the Marie Skłodowska-Curie PROBIST grant agreement No. 754510 (postdoctoral fellowship to R.J.) and from BIST Living Allowance Fellowship to A.T.-S. This work was supported by grants from the Spanish Ministry of Economy and Competitiveness [BFU2017-85152-P and FEDER to E.d.N. and PGC2018-094136-B-I00 and FEDER to F.P.], the AECC Foundation [PROYE18010POSA to F.P.] and the Government of Catalonia [2017 SGR 799 to E.d.N. and F.P.]. E.d.N. and F.P. are recipients of ICREA Acadèmia awards (Government of Catalonia). We gratefully acknowledge institutional funding from the Ministry of Science, Innovation and Universities through the Centres of Excellence Severo Ochoa Award, and from the CERCA Programme of the Government of Catalonia and the Unidad de Excelencia María de Maeztu, funded by the AEI (CEX2018-000792-M).

Conflicts of Interest: The authors declare no conflict of interest.

\section{References}

1. Knudson, A.G., Jr. Mutation and cancer: Statistical study of retinoblastoma. Proc. Natl. Acad. Sci. USA 1971, 68, 820-823. [CrossRef] [PubMed]

2. Lele, K.P.; Penrose, L.S.; Stallard, H.B. Chromosome deletion in a case of Retinoblastoma. Ann. Hum. Genet. 1963, 27, 171-174. [CrossRef] [PubMed]

3. Wilson, M.G.; Ebbin, A.J.; Towner, J.W.; Spencer, W.H. Chromosomal anomalies in patients with retinoblastoma. Clin. Genet. 1977, 12, 1-8. [CrossRef] [PubMed]

4. Comings, D.E. A general theory of carcinogenesis. Proc. Natl. Acad. Sci. USA 1973, 70, 3324-3328. [CrossRef]

5. $\quad$ Sparkes, R.S.; Murphree, A.L.; Lingua, R.W.; Sparkes, M.C.; Field, L.L.; Funderburk, S.J.; Benedict, W.F. Gene for hereditary retinoblastoma assigned to human chromosome 13 by linkage to esterase D. Science 1983, 219, 971-973. [CrossRef] 
6. Godbout, R.; Dryja, T.P.; Squire, J.; Gallie, B.L.; Phillips, R.A. Somatic inactivation of genes on chromosome 13 is a common event in retinoblastoma. Nature 1983, 304, 451-453. [CrossRef]

7. Lee, W.H.; Bookstein, R.; Hong, F.; Young, L.J.; Shew, J.Y.; Lee, E.Y. Human retinoblastoma susceptibility gene: Cloning, identification, and sequence. Science 1987, 235, 1394-1399. [CrossRef]

8. Claudio, P.P.; Tonini, T.; Giordano, A. The retinoblastoma family: Twins or distant cousins? Genome Biol. 2002, 3, reviews3012.1. [CrossRef]

9. Henley, S.A.; Dick, F.A. The retinoblastoma family of proteins and their regulatory functions in the mammalian cell division cycle Cell Div. 2012, 7, 10. [CrossRef]

10. Xiao, B.; Spencer, J.; Clements, A.; Ali-Khan, N.; Mittnacht, S.; Broceno, C.; Burghammer, M.; Perrakis, A.; Marmorstein, R.; Gamblin, S.J. Crystal structure of the retinoblastoma tumor suppressor protein bound to E2F and the molecular basis of its regulation. Proc. Natl. Acad. Sci. USA 2003, 100, 2363-2368. [CrossRef]

11. Hiebert, S.W.; Chellappan, S.P.; Horowitz, J.M.; Nevins, J.R. The interaction of RB with E2F coincides with an inhibition of the transcriptional activity of E2F. Genes Dev. 1992, 6, 177-185. [CrossRef] [PubMed]

12. Gu, W.; Schneider, J.W.; Condorelli, G.; Kaushal, S.; Mahdavi, V.; Nadal-Ginard, B. Interaction of myogenic factors and the retinoblastoma protein mediates muscle cell commitment and differentiation. Cell 1993, 72, 309-324. [CrossRef]

13. Chen, P.L.; Riley, D.J.; Chen-Kiang, S.; Lee, W.H. Retinoblastoma protein directly interacts with and activates the transcription factor NF-IL6. Proc. Natl. Acad. Sci. USA 1996, 93, 465-469. [CrossRef]

14. Chen, P.L.; Riley, D.J.; Chen, Y.; Lee, W.H. Retinoblastoma protein positively regulates terminal adipocyte differentiation through direct interaction with C/EBPs. Genes Dev. 1996, 10, 2794-2804. [CrossRef]

15. Gao, J.; Aksoy, B.A.; Dogrusoz, U.; Dresdner, G.; Gross, B.; Sumer, S.O.; Sun, Y.; Jacobsen, A.; Sinha, R.; Larsson, E.; et al Integrative analysis of complex cancer genomics and clinical profiles using the cBioPortal. Sci. Signal. 2013, 6, 11. [CrossRef]

16. Cerami, E.; Gao, J.; Dogrusoz, U.; Gross, B.E.; Sumer, S.O.; Aksoy, B.A.; Jacobsen, A.; Byrne, C.J.; Heuer, M.L.; Larsson, E.; et al. The cBio cancer genomics portal: An open platform for exploring multidimensional cancer genomics data. Cancer Discov. 2012, 2, 401-404. [CrossRef] [PubMed]

17. Dyson, N.J. RB1: A prototype tumor suppressor and an enigma. Genes Dev. 2016, 30, 1492-1502. [CrossRef]

18. Lee, C.; Chang, J.H.; Lee, H.S.; Cho, Y. Structural basis for the recognition of the E2F transactivation domain by the retinoblastoma tumor suppressor. Genes Dev. 2002, 16, 3199-3212. [CrossRef]

19. Chan, H.M.; Smith, L.; La Thangue, N.B. Role of LXCXE motif-dependent interactions in the activity of the retinoblastoma protein. Oncogene 2001, 20, 6152-6163. [CrossRef]

20. Dick, F.A.; Dyson, N. pRB contains an E2F1-specific binding domain that allows E2F1-induced apoptosis to be regulated separately from other E2F activities. Mol. Cell 2003, 12, 639-649. [CrossRef]

21. Chau, B.N.; Pan, C.W.; Wang, J.Y. Separation of anti-proliferation and anti-apoptotic functions of retinoblastoma protein through targeted mutations of its A/B domain. PLOS ONE 2006, 1, e82. [CrossRef] [PubMed]

22. Julian, L.M.; Palander, O.; Seifried, L.A.; Foster, J.E.; Dick, F.A. Characterization of an E2F1-specific binding domain in pRB and its implications for apoptotic regulation. Oncogene 2008, 27, 1572-1579. [CrossRef] [PubMed]

23. Rubin, S.M.; Gall, A.L.; Zheng, N.; Pavletich, N.P. Structure of the Rb C-terminal domain bound to E2F1-DP1: A mechanism for phosphorylation-induced E2F release. Cell 2005, 123, 1093-1106. [CrossRef] [PubMed]

24. Qin, X.Q.; Chittenden, T.; Livingston, D.M.; Kaelin, W.G., Jr. Identification of a growth suppression domain within the retinoblastoma gene product. Genes Dev. 1992, 6, 953-964. [CrossRef] [PubMed]

25. DeGregori, J.; Kowalik, T.; Nevins, J.R. Cellular targets for activation by the E2F1 transcription factor include DNA synthesis- and G1/S-regulatory genes. Mol. Cell Biol. 1995, 15, 4215-4224. [CrossRef]

26. Hagemeier, C.; Cook, A.; Kouzarides, T. The retinoblastoma protein binds E2F residues required for activation in vivo and TBP binding in vitro. Nucleic Acids Res. 1993, 21, 4998-5004. [CrossRef]

27. Weintraub, S.J.; Chow, K.N.; Luo, R.X.; Zhang, S.H.; He, S.; Dean, D.C. Mechanism of active transcriptional repression by the retinoblastoma protein. Nature 1995, 375, 812-815. [CrossRef]

28. Magnaghi-Jaulin, L.; Groisman, R.; Naguibneva, I.; Robin, P.; Lorain, S.; Le Villain, J.P.; Troalen, F.; Trouche, D.; Harel-Bellan, A. Retinoblastoma protein represses transcription by recruiting a histone deacetylase. Nature 1998, 391, 601-605. [CrossRef]

29. Brehm, A.; Miska, E.A.; McCance, D.J.; Reid, J.L.; Bannister, A.J.; Kouzarides, T. Retinoblastoma protein recruits histone deacetylase to repress transcription. Nature 1998, 391, 597-601. [CrossRef]

30. Luo, R.X.; Postigo, A.A.; Dean, D.C. Rb interacts with histone deacetylase to repress transcription. Cell 1998, 92, 463-473. [CrossRef]

31. Zhou, Y.; Jin, X.; Ma, J.; Ding, D.; Huang, Z.; Sheng, H.; Yan, Y.; Pan, Y.; Wei, T.; Wang, L.; et al. HDAC5 Loss Impairs RB Repression of Pro-Oncogenic Genes and Confers CDK4/6 Inhibitor Resistance in Cancer. Cancer Res. 2021, 81, 1486-1499. [CrossRef] [PubMed]

32. Nielsen, S.J.; Schneider, R.; Bauer, U.M.; Bannister, A.J.; Morrison, A.; O'Carroll, D.; Firestein, R.; Cleary, M.; Jenuwein, T.; Herrera, R.E.; et al. Rb targets histone H3 methylation and HP1 to promoters. Nature 2001, 412, 561-565. [CrossRef] [PubMed]

33. Ait-Si-Ali, S.; Guasconi, V.; Fritsch, L.; Yahi, H.; Sekhri, R.; Naguibneva, I.; Robin, P.; Cabon, F.; Polesskaya, A.; Harel-Bellan, A. A Suv39h-dependent mechanism for silencing S-phase genes in differentiating but not in cycling cells. EMBO J. 2004, 23, 605-615. [CrossRef] 
34. Dunaief, J.L.; Strober, B.E.; Guha, S.; Khavari, P.A.; Alin, K.; Luban, J.; Begemann, M.; Crabtree, G.R.; Goff, S.P. The retinoblastoma protein and BRG1 form a complex and cooperate to induce cell cycle arrest. Cell 1994, 79, 119-130. [CrossRef]

35. Singh, P.; Coe, J.; Hong, W. A role for retinoblastoma protein in potentiating transcriptional activation by the glucocorticoid receptor. Nature 1995, 374, 562-565. [CrossRef]

36. Schnitzler, G.; Sif, S.; Kingston, R.E. Human SWI/SNF interconverts a nucleosome between its base state and a stable remodeled state. Cell 1998, 94, 17-27. [CrossRef]

37. Cobrinik, D. Pocket proteins and cell cycle control. Oncogene 2005, 24, 2796-2809. [CrossRef]

38. Robertson, K.D.; Ait-Si-Ali, S.; Yokochi, T.; Wade, P.A.; Jones, P.L.; Wolffe, A.P. DNMT1 forms a complex with Rb, E2F1 and HDAC1 and represses transcription from E2F-responsive promoters. Nat. Genet. 2000, 25, 338-342. [CrossRef]

39. Ishak, C.A.; Marshall, A.E.; Passos, D.T.; White, C.R.; Kim, S.J.; Cecchini, M.J.; Ferwati, S.; MacDonald, W.A.; Howlett, C.J.; Welch, I.D.; et al. An RB-EZH2 Complex Mediates Silencing of Repetitive DNA Sequences. Mol. Cell 2016, 64, $1074-1087$. [CrossRef]

40. Liu, X.; Marmorstein, R. When viral oncoprotein meets tumor suppressor: A structural view. Genes Dev. 2006, 20 , $2332-2337$. [CrossRef]

41. Lee, J.O.; Russo, A.A.; Pavletich, N.P. Structure of the retinoblastoma tumour-suppressor pocket domain bound to a peptide from HPV E7. Nature 1998, 391, 859-865. [CrossRef] [PubMed]

42. Dyson, N.; Howley, P.M.; Munger, K.; Harlow, E. The human papilloma virus-16 E7 oncoprotein is able to bind to the retinoblastoma gene product. Science 1989, 243, 934-937. [CrossRef] [PubMed]

43. DeCaprio, J.A.; Ludlow, J.W.; Figge, J.; Shew, J.Y.; Huang, C.M.; Lee, W.H.; Marsilio, E.; Paucha, E.; Livingston, D.M. SV40 large tumor antigen forms a specific complex with the product of the retinoblastoma susceptibility gene. Cell 1988, 54, 275-283. [CrossRef]

44. Whyte, P.; Buchkovich, K.J.; Horowitz, J.M.; Friend, S.H.; Raybuck, M.; Weinberg, R.A.; Harlow, E. Association between an oncogene and an anti-oncogene: The adenovirus E1A proteins bind to the retinoblastoma gene product. Nature 1988, 334, 124-129. [CrossRef]

45. Singh, M.; Krajewski, M.; Mikolajka, A.; Holak, T.A. Molecular determinants for the complex formation between the retinoblastoma protein and LXCXE sequences. J. Biol. Chem. 2005, 280, 37868-37876. [CrossRef]

46. Morrison, A.J.; Sardet, C.; Herrera, R.E. Retinoblastoma protein transcriptional repression through histone deacetylation of a single nucleosome. Mol. Cell Biol. 2002, 22, 856-865. [CrossRef]

47. Ferreira, R.; Magnaghi-Jaulin, L.; Robin, P.; Harel-Bellan, A.; Trouche, D. The three members of the pocket proteins family share the ability to repress E2F activity through recruitment of a histone deacetylase. Proc. Natl. Acad. Sci. USA 1998, 95, 10493-10498. [CrossRef]

48. Chen, H.Z.; Tsai, S.Y.; Leone, G. Emerging roles of E2Fs in cancer: An exit from cell cycle control. Nat. Rev. Cancer 2009, 9, 785-797. [CrossRef] [PubMed]

49. Dyson, N. The regulation of E2F by pRB-family proteins. Genes Dev. 1998, 12, 2245-2262. [CrossRef]

50. Lees, J.A.; Saito, M.; Vidal, M.; Valentine, M.; Look, T.; Harlow, E.; Dyson, N.; Helin, K. The retinoblastoma protein binds to a family of E2F transcription factors. Mol. Cell Biol. 1993, 13, 7813-7825.

51. Moberg, K.; Starz, M.A.; Lees, J.A. E2F-4 switches from p130 to p107 and pRB in response to cell cycle reentry. Mol. Cell Biol. 1996, 16, 1436-1449. [CrossRef]

52. Humbert, P.O.; Rogers, C.; Ganiatsas, S.; Landsberg, R.L.; Trimarchi, J.M.; Dandapani, S.; Brugnara, C.; Erdman, S.; Schrenzel, M.; Bronson, R.T.; et al. E2F4 is essential for normal erythrocyte maturation and neonatal viability. Mol. Cell 2000, 6, 281-291. [CrossRef]

53. Danielian, P.S.; Hess, R.A.; Lees, J.A. E2f4 and E2f5 are essential for the development of the male reproductive system. Cell Cycle 2016, 15, 250-260. [CrossRef] [PubMed]

54. Cuitino, M.C.; Pecot, T.; Sun, D.; Kladney, R.; Okano-Uchida, T.; Shinde, N.; Saeed, R.; Perez-Castro, A.J.; Webb, A.; Liu, T.; et al Two Distinct E2F Transcriptional Modules Drive Cell Cycles and Differentiation. Cell Rep. 2019, 27, 3547-3560. [CrossRef]

55. Miccadei, S.; Provenzano, C.; Mojzisek, M.; Natali, P.G.; Civitareale, D. Retinoblastoma protein acts as Pax 8 transcriptional coactivator. Oncogene 2005, 24, 6993-7001. [CrossRef]

56. Thomas, D.M.; Carty, S.A.; Piscopo, D.M.; Lee, J.S.; Wang, W.F.; Forrester, W.C.; Hinds, P.W. The retinoblastoma protein acts as a transcriptional coactivator required for osteogenic differentiation. Mol. Cell 2001, 8, 303-316. [CrossRef]

57. Kadri, Z.; Shimizu, R.; Ohneda, O.; Maouche-Chretien, L.; Gisselbrecht, S.; Yamamoto, M.; Romeo, P.H.; Leboulch, P.; Chretien, S. Direct binding of pRb/E2F-2 to GATA-1 regulates maturation and terminal cell division during erythropoiesis. PLoS. Biol. 2009, 7, e1000123. [CrossRef] [PubMed]

58. MacLellan, W.R.; Xiao, G.; Abdellatif, M.; Schneider, M.D. A novel Rb- and p300-binding protein inhibits transactivation by MyoD. Mol. Cell Biol. 2000, 20, 8903-8915. [CrossRef] [PubMed]

59. Iavarone, A.; Garg, P.; Lasorella, A.; Hsu, J.; Israel, M.A. The helix-loop-helix protein Id-2 enhances cell proliferation and binds to the retinoblastoma protein. Genes Dev. 1994, 8, 1270-1284. [CrossRef]

60. Takebayashi, T.; Higashi, H.; Sudo, H.; Ozawa, H.; Suzuki, E.; Shirado, O.; Katoh, H.; Hatakeyama, M. NF-kappa B-dependent induction of cyclin D1 by retinoblastoma protein (pRB) family proteins and tumor-derived pRB mutants. J. Biol. Chem. 2003, 278, 14897-14905. [CrossRef] 
61. Jin, X.; Ding, D.; Yan, Y.; Li, H.; Wang, B.; Ma, L.; Ye, Z.; Ma, T.; Wu, Q.; Rodrigues, D.N.; et al. Phosphorylated RB Promotes Cancer Immunity by Inhibiting NF-kappaB Activation and PD-L1 Expression. Mol. Cell 2019, 73, 22-35. [CrossRef] [PubMed]

62. Benevolenskaya, E.V.; Murray, H.L.; Branton, P.; Young, R.A.; Kaelin, W.G., Jr. Binding of pRB to the PHD protein RBP2 promotes cellular differentiation. Mol. Cell 2005, 18, 623-635. [CrossRef] [PubMed]

63. Isaac, C.E.; Francis, S.M.; Martens, A.L.; Julian, L.M.; Seifried, L.A.; Erdmann, N.; Binne, U.K.; Harrington, L.; Sicinski, P.; Berube, N.G.; et al. The retinoblastoma protein regulates pericentric heterochromatin. Mol. Cell Biol. 2006, 26, 3659-3671. [CrossRef]

64. Gonzalo, S.; Garcia-Cao, M.; Fraga, M.F.; Schotta, G.; Peters, A.H.; Cotter, S.E.; Eguia, R.; Dean, D.C.; Esteller, M.; Jenuwein, T.; et al. Role of the RB1 family in stabilizing histone methylation at constitutive heterochromatin. Nat. Cell Biol. 2005, 7, 420-428. [CrossRef] [PubMed]

65. Li, M.; Zhang, P. The function of APC/CCdh1 in cell cycle and beyond. Cell Div. 2009, 4, 2. [CrossRef] [PubMed]

66. Nakayama, K.I.; Nakayama, K. Regulation of the cell cycle by SCF-type ubiquitin ligases. Semin. Cell Dev. Biol. 2005, 16, 323-333. [CrossRef] [PubMed]

67. Ji, P.; Jiang, H.; Rekhtman, K.; Bloom, J.; Ichetovkin, M.; Pagano, M.; Zhu, L. An Rb-Skp2-p27 pathway mediates acute cell cycle inhibition by $\mathrm{Rb}$ and is retained in a partial-penetrance $\mathrm{Rb}$ mutant. Mol. Cell 2004, 16, 47-58. [CrossRef] [PubMed]

68. Binne, U.K.; Classon, M.K.; Dick, F.A.; Wei, W.; Rape, M.; Kaelin, W.G.; Naar, A.M., Jr.; Dyson, N.J. Retinoblastoma protein and anaphase-promoting complex physically interact and functionally cooperate during cell-cycle exit. Nat. Cell Biol. 2007, 9, 225-232. [CrossRef]

69. Ramanujan, A.; Tiwari, S. APC/C and retinoblastoma interaction: Cross-talk of retinoblastoma protein with the ubiquitin proteasome pathway. Biosci. Rep. 2016, 36, e00377. [CrossRef]

70. Wiggs, J.; Nordenskjold, M.; Yandell, D.; Rapaport, J.; Grondin, V.; Janson, M.; Werelius, B.; Petersen, R.; Craft, A.; Riedel, K.; et al. Prediction of the risk of hereditary retinoblastoma, using DNA polymorphisms within the retinoblastoma gene. N. Engl. J. Med. 1988, 318, 151-157. [CrossRef]

71. Friend, S.H.; Horowitz, J.M.; Gerber, M.R.; Wang, X.F.; Bogenmann, E.; Li, F.P.; Weinberg, R.A. Deletions of a DNA sequence in retinoblastomas and mesenchymal tumors: Organization of the sequence and its encoded protein. Proc. Natl. Acad. Sci. USA 1987, 84, 9059-9063. [CrossRef] [PubMed]

72. Berge, E.O.; Knappskog, S.; Geisler, S.; Staalesen, V.; Pacal, M.; Borresen-Dale, A.L.; Puntervoll, P.; Lillehaug, J.R.; Lonning, P.E. Identification and characterization of retinoblastoma gene mutations disturbing apoptosis in human breast cancers. Mol. Cancer 2010, 9, 173. [CrossRef]

73. Condorelli, R.; Spring, L.; O’Shaughnessy, J.; Lacroix, L.; Bailleux, C.; Scott, V.; Dubois, J.; Nagy, R.J.; Lanman, R.B.; Iafrate, A.J.; et al. Polyclonal RB1 mutations and acquired resistance to CDK 4/6 inhibitors in patients with metastatic breast cancer. Ann. Oncol. 2018, 29, 640-645. [CrossRef] [PubMed]

74. McCartney, A.; Migliaccio, I.; Bonechi, M.; Biagioni, C.; Romagnoli, D.; De, L.F.; Galardi, F.; Risi, E.; De, S.I.; Benelli, M.; et al. Mechanisms of Resistance to CDK4/6 Inhibitors: Potential Implications and Biomarkers for Clinical Practice. Front. Oncol. 2019, 9, 666. [CrossRef]

75. Gansauge, S.; Gansauge, F.; Ramadani, M.; Stobbe, H.; Rau, B.; Harada, N.; Beger, H.G. Overexpression of cyclin D1 in human pancreatic carcinoma is associated with poor prognosis. Cancer Res. 1997, 57, 1634-1637.

76. Wang, L.; Shao, Z.M. Cyclin e expression and prognosis in breast cancer patients: A meta-analysis of published studies. Cancer Investig. 2006, 24, 581-587. [CrossRef]

77. Tsihlias, J.; Kapusta, L.; Slingerland, J. The prognostic significance of altered cyclin-dependent kinase inhibitors in human cancer Annu. Rev. Med. 1999, 50, 401-423. [CrossRef]

78. Straume, O.; Sviland, L.; Akslen, L.A. Loss of nuclear p16 protein expression correlates with increased tumor cell proliferation (Ki-67) and poor prognosis in patients with vertical growth phase melanoma. Clin. Cancer Res. 2000, 6, 1845-1853. [PubMed]

79. Stirzaker, C.; Millar, D.S.; Paul, C.L.; Warnecke, P.M.; Harrison, J.; Vincent, P.C.; Frommer, M.; Clark, S.J. Extensive DNA methylation spanning the Rb promoter in retinoblastoma tumors. Cancer Res. 1997, 57, 2229-2237.

80. Ohtani-Fujita, N.; Fujita, T.; Aoike, A.; Osifchin, N.E.; Robbins, P.D.; Sakai, T. CpG methylation inactivates the promoter activity of the human retinoblastoma tumor-suppressor gene. Oncogene 1993, 8, 1063-1067.

81. Gonzalez-Gomez, P.; Bello, M.J.; Arjona, D.; Lomas, J.; Alonso, M.E.; De Campos, J.M.; Vaquero, J.; Isla, A.; Gutierrez, M.; Rey, J.A Promoter hypermethylation of multiple genes in astrocytic gliomas. Int. J. Oncol. 2003, 22, 601-608. [PubMed]

82. Price, E.A.; Kolkiewicz, K.; Patel, R.; Hashim, S.; Karaa, E.; Scheimberg, I.; Sagoo, M.S.; Reddy, M.A.; Onadim, Z. Detection and reporting of RB1 promoter hypermethylation in diagnostic screening. Ophthalmic Genet. 2018, 39, 526-531. [CrossRef] [PubMed]

83. Gonzalez-Gomez, P.; Bello, M.J.; Alonso, M.E.; Arjona, D.; Lomas, J.; De Campos, J.M.; Isla, A.; Rey, J.A. CpG island methylation status and mutation analysis of the RB1 gene essential promoter region and protein-binding pocket domain in nervous system tumours. Br. J. Cancer 2003, 88, 109-114. [CrossRef] [PubMed]

84. Witkiewicz, A.K.; Knudsen, K.E.; Dicker, A.P.; Knudsen, E.S. The meaning of p16(ink4a) expression in tumors: Functional significance, clinical associations and future developments. Cell Cycle 2011, 10, 2497-2503. [CrossRef]

85. Asghar, U.; Witkiewicz, A.K.; Turner, N.C.; Knudsen, E.S. The history and future of targeting cyclin-dependent kinases in cancer therapy. Nat. Rev. Drug Discov. 2015, 14, 130-146. [CrossRef] 
86. Cam, H.; Dynlacht, B.D. Emerging roles for E2F: Beyond the G1/S transition and DNA replication. Cancer Cell 2003, 3, 311-316. [CrossRef]

87. Fry, D.W.; Harvey, P.J.; Keller, P.R.; Elliott, W.L.; Meade, M.; Trachet, E.; Albassam, M.; Zheng, X.; Leopold, W.R.; Pryer, N.K.; et al. Specific inhibition of cyclin-dependent kinase 4/6 by PD 0332991 and associated antitumor activity in human tumor xenografts. Mol. Cancer Ther. 2004, 3, 1427-1438.

88. Musgrove, E.A.; Caldon, C.E.; Barraclough, J.; Stone, A.; Sutherland, R.L. Cyclin D as a therapeutic target in cancer. Nat. Rev. Cancer 2011, 11, 558-572. [CrossRef]

89. Sherr, C.J.; Beach, D.; Shapiro, G.I. Targeting CDK4 and CDK6: From Discovery to Therapy. Cancer Discov. 2016, 6, 353-367. [CrossRef]

90. Patnaik, A.; Rosen, L.S.; Tolaney, S.M.; Tolcher, A.W.; Goldman, J.W.; Gandhi, L.; Papadopoulos, K.P.; Beeram, M.; Rasco, D.W.; Hilton, J.F.; et al. Efficacy and Safety of Abemaciclib, an Inhibitor of CDK4 and CDK6, for Patients with Breast Cancer, Non-Small Cell Lung Cancer, and Other Solid Tumors. Cancer Discov. 2016, 6, 740-753. [CrossRef]

91. DeMichele, A.; Clark, A.S.; Tan, K.S.; Heitjan, D.F.; Gramlich, K.; Gallagher, M.; Lal, P.; Feldman, M.; Zhang, P.; Colameco, C.; et al. CDK 4/6 inhibitor palbociclib (PD0332991) in Rb+ advanced breast cancer: Phase II activity, safety, and predictive biomarker assessment. Clin. Cancer Res. 2015, 21, 995-1001. [CrossRef]

92. Finn, R.S.; Dering, J.; Conklin, D.; Kalous, O.; Cohen, D.J.; Desai, A.J.; Ginther, C.; Atefi, M.; Chen, I.; Fowst, C.; et al. PD 0332991, a selective cyclin D kinase 4/6 inhibitor, preferentially inhibits proliferation of luminal estrogen receptor-positive human breast cancer cell lines in vitro. Breast Cancer Res. 2009, 11, R77. [CrossRef] [PubMed]

93. Knudsen, E.S.; Witkiewicz, A.K. The Strange Case of CDK4/6 Inhibitors: Mechanisms, Resistance, and Combination Strategies. Trends Cancer 2017, 3, 39-55. [CrossRef] [PubMed]

94. Brantley, M.A., Jr.; Harbour, J.W. Inactivation of retinoblastoma protein in uveal melanoma by phosphorylation of sites in the COOH-terminal region. Cancer Res. 2000, 60, 4320-4323.

95. Hinds, P.W.; Mittnacht, S.; Dulic, V.; Arnold, A.; Reed, S.I.; Weinberg, R.A. Regulation of retinoblastoma protein functions by ectopic expression of human cyclins. Cell 1992, 70, 993-1006. [CrossRef]

96. Lundberg, A.S.; Weinberg, R.A. Functional inactivation of the retinoblastoma protein requires sequential modification by at least two distinct cyclin-cdk complexes. Mol. Cell Biol. 1998, 18, 753-761. [CrossRef]

97. Alsina, M.; Landolfi, S.; Aura, C.; Caci, K.; Jimenez, J.; Prudkin, L.; Castro, S.; Moreno, D.; Navalpotro, B.; Tabernero, J.; et al. Cyclin E amplification/overexpression is associated with poor prognosis in gastric cancer. Ann. Oncol. 2015, 26, 438-439. [CrossRef]

98. Velez-Cruz, R.; Manickavinayaham, S.; Biswas, A.K.; Clary, R.W.; Premkumar, T.; Cole, F.; Johnson, D.G. RB localizes to DNA double-strand breaks and promotes DNA end resection and homologous recombination through the recruitment of BRG1. Genes Dev. 2016, 30, 2500-2512. [CrossRef]

99. Hays, E.; Nettleton, E.; Carter, C.; Morales, M.; Vo, L.; Passo, M.; Velez-Cruz, R. The SWI/SNF ATPase BRG1 stimulates DNA end resection and homologous recombination by reducing nucleosome density at DNA double strand breaks and by promoting the recruitment of the CtIP nuclease. Cell Cycle 2020, 19, 3096-3114. [CrossRef]

100. Jiang, Y.; Yam, J.C.; Tham, C.C.; Pang, C.P.; Chu, W.K. RB Regulates DNA Double Strand Break Repair Pathway Choice by Mediating CtIP Dependent End Resection. Int. J. Mol. Sci. 2020, 21, 9176. [CrossRef]

101. Chen, L.; Nievera, C.J.; Lee, A.Y.; Wu, X. Cell cycle-dependent complex formation of BRCA1.CtIP.MRN is important for DNA double-strand break repair. J. Biol. Chem. 2008, 283, 7713-7720. [CrossRef] [PubMed]

102. Cook, R.; Zoumpoulidou, G.; Luczynski, M.T.; Rieger, S.; Moquet, J.; Spanswick, V.J.; Hartley, J.A.; Rothkamm, K.; Huang, P.H.; Mittnacht, S. Direct involvement of retinoblastoma family proteins in DNA repair by non-homologous end-joining. Cell Rep. 2015, 10, 2006-2018. [CrossRef]

103. Siddiqui, H.; Fox, S.R.; Gunawardena, R.W.; Knudsen, E.S. Loss of RB compromises specific heterochromatin modifications and modulates HP1alpha dynamics. J. Cell Physiol. 2007, 211, 131-137. [CrossRef] [PubMed]

104. Coschi, C.H.; Martens, A.L.; Ritchie, K.; Francis, S.M.; Chakrabarti, S.; Berube, N.G.; Dick, F.A. Mitotic chromosome condensation mediated by the retinoblastoma protein is tumor-suppressive. Genes Dev. 2010, 24, 1351-1363. [CrossRef]

105. Coschi, C.H.; Ishak, C.A.; Gallo, D.; Marshall, A.; Talluri, S.; Wang, J.; Cecchini, M.J.; Martens, A.L.; Percy, V.; Welch, I.; et al. Haploinsufficiency of an RB-E2F1-Condensin II complex leads to aberrant replication and aneuploidy. Cancer Discov. 2014, 4, 840-853. [CrossRef] [PubMed]

106. Wang, S.; Nath, N.; Minden, A.; Chellappan, S. Regulation of Rb and E2F by signal transduction cascades: Divergent effects of JNK1 and p38 kinases. EMBO J. 1999, 18, 1559-1570. [CrossRef]

107. Manning, A.L.; Longworth, M.S.; Dyson, N.J. Loss of pRB causes centromere dysfunction and chromosomal instability. Genes Dev. 2010, 24, 1364-1376. [CrossRef]

108. Gao, C.; Furge, K.; Koeman, J.; Dykema, K.; Su, Y.; Cutler, M.L.; Werts, A.; Haak, P.; Vande Woude, G.F. Chromosome instability, chromosome transcriptome, and clonal evolution of tumor cell populations. Proc. Natl. Acad. Sci. USA 2007, 104, 8995-9000. [CrossRef]

109. Ruscetti, M.; Leibold, J.; Bott, M.J.; Fennell, M.; Kulick, A.; Salgado, N.R.; Chen, C.C.; Ho, Y.J.; Sanchez-Rivera, F.J.; Feucht, J.; et al. NK cell-mediated cytotoxicity contributes to tumor control by a cytostatic drug combination. Science 2018, 362, 1416-1422. [CrossRef] 
110. Deng, J.; Wang, E.S.; Jenkins, R.W.; Li, S.; Dries, R.; Yates, K.; Chhabra, S.; Huang, W.; Liu, H.; Aref, A.R.; et al. CDK4/6 Inhibition Augments Antitumor Immunity by Enhancing T-cell Activation. Cancer Discov. 2018, 8, 216-233. [CrossRef]

111. Goel, S.; DeCristo, M.J.; Watt, A.C.; BrinJones, H.; Sceneay, J.; Li, B.B.; Khan, N.; Ubellacker, J.M.; Xie, S.; Metzger-Filho, O.; et al. CDK4/ 6 inhibition triggers anti-tumour immunity. Nature 2017, 548, 471-475. [CrossRef] [PubMed]

112. Markey, M.P.; Bergseid, J.; Bosco, E.E.; Stengel, K.; Xu, H.; Mayhew, C.N.; Schwemberger, S.J.; Braden, W.A.; Jiang, Y.; Babcock, G.F.; et al. Loss of the retinoblastoma tumor suppressor: Differential action on transcriptional programs related to cell cycle control and immune function. Oncogene 2007, 26, 6307-6318. [CrossRef] [PubMed]

113. Velez-Cruz, R.; Johnson, D.G. The Retinoblastoma (RB) Tumor Suppressor: Pushing Back against Genome Instability on Multiple Fronts. Int. J. Mol. Sci. 2017, 18, 1776. [CrossRef] [PubMed]

114. Dick, F.A.; Goodrich, D.W.; Sage, J.; Dyson, N.J. Non-canonical functions of the RB protein in cancer. Nat. Rev. Cancer 2018, 18, 442-451. [CrossRef] [PubMed]

115. Smith, C.C.; Selitsky, S.R.; Chai, S.; Armistead, P.M.; Vincent, B.G.; Serody, J.S. Alternative tumour-specific antigens. Nat. Rev. Cancer 2019, 19, 465-478. [CrossRef]

116. Upadhyay, S.; Sharma, N.; Gupta, K.B.; Dhiman, M. Role of immune system in tumor progression and carcinogenesis. J. Cell Biochem. 2018, 119, 5028-5042. [CrossRef]

117. Mardis, E.R. Neoantigens and genome instability: Impact on immunogenomic phenotypes and immunotherapy response. Genome Med. 2019, 11, 71. [CrossRef]

118. Chae, Y.K.; Viveiros, P.; Lopes, G.; Sukhadia, B.; Sheikh, M.M.; Saravia, D.; Florou, V.; Sokol, E.S.; Frampton, G.M.; Chalmers, Z.R.; et al. Clinical and Immunological Implications of Frameshift Mutations in Lung Cancer. J. Thorac. Oncol. 2019, 14, 1807-1817. [CrossRef]

119. Turajlic, S.; Litchfield, K.; Xu, H.; Rosenthal, R.; McGranahan, N.; Reading, J.L.; Wong, Y.N.S.; Rowan, A.; Kanu, N.; Al, B.M.; et al. Insertion-and-deletion-derived tumour-specific neoantigens and the immunogenic phenotype: A pan-cancer analysis. Lancet Oncol. 2017, 18, 1009-1021. [CrossRef]

120. Samstein, R.M.; Lee, C.H.; Shoushtari, A.N.; Hellmann, M.D.; Shen, R.; Janjigian, Y.Y.; Barron, D.A.; Zehir, A.; Jordan, E.J.; Omuro, A.; et al. Tumor mutational load predicts survival after immunotherapy across multiple cancer types. Nat. Genet. 2019, 51, 202-206. [CrossRef]

121. Goodman, A.M.; Kato, S.; Bazhenova, L.; Patel, S.P.; Frampton, G.M.; Miller, V.; Stephens, P.J.; Daniels, G.A.; Kurzrock, R. Tumor Mutational Burden as an Independent Predictor of Response to Immunotherapy in Diverse Cancers. Mol. Cancer Ther. 2017, 16, 2598-2608. [CrossRef] [PubMed]

122. Hellmann, M.D.; Ciuleanu, T.E.; Pluzanski, A.; Lee, J.S.; Otterson, G.A.; Audigier-Valette, C.; Minenza, E.; Linardou, H.; Burgers, S.; Salman, P.; et al. Nivolumab plus Ipilimumab in Lung Cancer with a High Tumor Mutational Burden. N. Engl. J. Med. 2018, 378, 2093-2104. [CrossRef] [PubMed]

123. Bugide, S.; Janostiak, R.; Wajapeyee, N. Epigenetic Mechanisms Dictating Eradication of Cancer by Natural Killer Cells. Trends Cancer 2018, 4, 553-566. [CrossRef]

124. Lentine, B.; Antonucci, L.; Hunce, R.; Edwards, J.; Marallano, V.; Krucher, N.A. Dephosphorylation of threonine-821 of the retinoblastoma tumor suppressor protein $(\mathrm{Rb})$ is required for apoptosis induced by UV and Cdk inhibition. Cell Cycle 2012, 11, 3324-3330. [CrossRef] [PubMed]

125. Gubern, A.; Joaquin, M.; Marques, M.; Maseres, P.; Garcia-Garcia, J.; Amat, R.; Gonzalez-Nunez, D.; Oliva, B.; Real, F.X.; de Nadal, E.; et al. The N-Terminal Phosphorylation of RB by p38 Bypasses Its Inactivation by CDKs and Prevents Proliferation in Cancer Cells. Mol. Cell 2016, 64, 25-36. [CrossRef]

126. Hassler, M.; Singh, S.; Yue, W.W.; Luczynski, M.; Lakbir, R.; Sanchez-Sanchez, F.; Bader, T.; Pearl, L.H.; Mittnacht, S. Crystal structure of the retinoblastoma protein $\mathrm{N}$ domain provides insight into tumor suppression, ligand interaction, and holoprotein architecture. Mol. Cell 2007, 28, 371-385. [CrossRef] [PubMed]

127. Dix, M.M.; Simon, G.M.; Wang, C.; Okerberg, E.; Patricelli, M.P.; Cravatt, B.F. Functional interplay between caspase cleavage and phosphorylation sculpts the apoptotic proteome. Cell 2012, 150, 426-440. [CrossRef]

128. Burke, J.R.; Deshong, A.J.; Pelton, J.G.; Rubin, S.M. Phosphorylation-induced conformational changes in the retinoblastoma protein inhibit E2F transactivation domain binding. J. Biol. Chem. 2010, 285, 16286-16293. [CrossRef]

129. Delston, R.B.; Matatall, K.A.; Sun, Y.; Onken, M.D.; Harbour, J.W. p38 phosphorylates Rb on Ser567 by a novel, cell cycleindependent mechanism that triggers $\mathrm{Rb}-\mathrm{Hdm} 2$ interaction and apoptosis. Oncogene 2011, 30, 588-599. [CrossRef]

130. Rousset-Roman, A.; Rebolloso-Gomez, Y.; Olivares-Illana, V. Expression and purification of the recombinant full-length retinoblastoma protein and characterisation of its interaction with the oncoprotein HDM2. Protein Expr. Purif. 2019, 162, 62-66. [CrossRef]

131. Knudsen, E.S.; Wang, J.Y. Dual mechanisms for the inhibition of E2F binding to RB by cyclin-dependent kinase-mediated RB phosphorylation. Mol. Cell Biol. 1997, 17, 5771-5783. [CrossRef]

132. Zarkowska, T.; Sally, U.; Harlow, E.; Mittnacht, S. Monoclonal antibodies specific for underphosphorylated retinoblastoma protein identify a cell cycle regulated phosphorylation site targeted by CDKs. Oncogene 1997, 14, 249-254. [CrossRef] [PubMed]

133. Inoue, Y.; Kitagawa, M.; Taya, Y. Phosphorylation of pRB at Ser612 by Chk1/2 leads to a complex between pRB and E2F-1 after DNA damage. EMBO J. 2007, 26, 2083-2093. [CrossRef]

134. Ledl, A.; Schmidt, D.; Muller, S. Viral oncoproteins E1A and E7 and cellular LxCxE proteins repress SUMO modification of the retinoblastoma tumor suppressor. Oncogene 2005, 24, 3810-3818. [CrossRef] [PubMed] 
135. Sharma, P.; Kuehn, M.R. SENP1-modulated sumoylation regulates retinoblastoma protein (RB) and Lamin A/C interaction and stabilization. Oncogene 2016, 35, 6429-6438. [CrossRef] [PubMed]

136. Kim, K.Y.; Wang, D.H.; Campbell, M.; Huerta, S.B.; Shevchenko, B.; Izumiya, C.; Izumiya, Y. PRMT4-mediated arginine methylation negatively regulates retinoblastoma tumor suppressor protein and promotes E2F-1 dissociation. Mol. Cell Biol. 2015, 35, 238-248. [CrossRef] [PubMed]

137. Kitagawa, M.; Higashi, H.; Jung, H.K.; Suzuki-Takahashi, I.; Ikeda, M.; Tamai, K.; Kato, J.; Segawa, K.; Yoshida, E.; Nishimura, S.; et al. The consensus motif for phosphorylation by cyclin D1-Cdk4 is different from that for phosphorylation by cyclin A/E-Cdk2. EMBO J. 1996, 15, 7060-7069. [CrossRef]

138. Nair, J.S.; Ho, A.L.; Tse, A.N.; Coward, J.; Cheema, H.; Ambrosini, G.; Keen, N.; Schwartz, G.K. Aurora B kinase regulates the postmitotic endoreduplication checkpoint via phosphorylation of the retinoblastoma protein at serine 780. Mol. Biol. Cell 2009, 20, 2218-2228. [CrossRef]

139. Mishra, S.; Melino, G.; Murphy, L.J. Transglutaminase 2 kinase activity facilitates protein kinase A-induced phosphorylation of retinoblastoma protein. J. Biol. Chem. 2007, 282, 18108-18115. [CrossRef]

140. Nagano, K.; Itagaki, C.; Izumi, T.; Nunomura, K.; Soda, Y.; Tani, K.; Takahashi, N.; Takenawa, T.; Isobe, T. Rb plays a role in survival of Abl-dependent human tumor cells as a downstream effector of Abl tyrosine kinase. Oncogene 2006, 25, 493-502. [CrossRef]

141. Carr, S.M.; Munro, S.; Kessler, B.; Oppermann, U.; La Thangue, N.B. Interplay between lysine methylation and Cdk phosphorylation in growth control by the retinoblastoma protein. EMBO J. 2011, 30, 317-327. [CrossRef] [PubMed]

142. Carr, S.M.; Munro, S.; Sagum, C.A.; Fedorov, O.; Bedford, M.T.; La Thangue, N.B. Tudor-domain protein PHF20L1 reads lysine methylated retinoblastoma tumour suppressor protein. Cell Death Differ. 2017, 24, 2139-2149. [CrossRef] [PubMed]

143. Youn, C.K.; Cho, H.J.; Kim, S.H.; Kim, H.B.; Kim, M.H.; Chang, I.Y.; Lee, J.S.; Chung, M.H.; Hahm, K.S.; You, H.J. Bcl-2 expression suppresses mismatch repair activity through inhibition of E2F transcriptional activity. Nat. Cell Biol. 2005, 7, 137-147. [CrossRef] [PubMed]

144. Kim, S.J.; MacDonald, J.I.; Dick, F.A. Phosphorylation of the RB C-terminus regulates condensin II release from chromatin. J. Biol. Chem. 2021, 296, 100108. [CrossRef]

145. Mertins, P.; Qiao, J.W.; Patel, J.; Udeshi, N.D.; Clauser, K.R.; Mani, D.R.; Burgess, M.W.; Gillette, M.A.; Jaffe, J.D.; Carr, S.A. Integrated proteomic analysis of post-translational modifications by serial enrichment. Nat. Methods 2013, 10, 634-637. [CrossRef]

146. Mertins, P.; Mani, D.R.; Ruggles, K.V.; Gillette, M.A.; Clauser, K.R.; Wang, P.; Wang, X.; Qiao, J.W.; Cao, S.; Petralia, F.; et al Proteogenomics connects somatic mutations to signalling in breast cancer. Nature 2016, 534, 55-62. [CrossRef]

147. Markham, D.; Munro, S.; Soloway, J.; O'Connor, D.P.; La Thangue, N.B. DNA-damage-responsive acetylation of pRb regulates binding to E2F-1. EMBO Rep. 2006, 7, 192-198. [CrossRef]

148. Nguyen, D.X.; Baglia, L.A.; Huang, S.M.; Baker, C.M.; McCance, D.J. Acetylation regulates the differentiation-specific functions of the retinoblastoma protein. EMBO J. 2004, 23, 1609-1618. [CrossRef]

149. Alcolea, M.P.; Casado, P.; Rodriguez-Prados, J.C.; Vanhaesebroeck, B.; Cutillas, P.R. Phosphoproteomic analysis of leukemia cells under basal and drug-treated conditions identifies markers of kinase pathway activation and mechanisms of resistance. Mol. Cell Proteomics 2012, 11, 453-466. [CrossRef]

150. Kettenbach, A.N.; Schweppe, D.K.; Faherty, B.K.; Pechenick, D.; Pletnev, A.A.; Gerber, S.A. Quantitative phosphoproteomics identifies substrates and functional modules of Aurora and Polo-like kinase activities in mitotic cells. Sci. Signal. 2011, 4, rs5. [CrossRef]

151. Wang, Y.T.; Tsai, C.F.; Hong, T.C.; Tsou, C.C.; Lin, P.Y.; Pan, S.H.; Hong, T.M.; Yang, P.C.; Sung, T.Y.; Hsu, W.L.; et al. An informaticsassisted label-free quantitation strategy that depicts phosphoproteomic profiles in lung cancer cell invasion. J. Proteome Res. 2010, 9, 5582-5597. [CrossRef] [PubMed]

152. Stokes, M.P.; Farnsworth, C.L.; Moritz, A.; Silva, J.C.; Jia, X.; Lee, K.A.; Guo, A.; Polakiewicz, R.D.; Comb, M.J. PTMScan direct: Identification and quantification of peptides from critical signaling proteins by immunoaffinity enrichment coupled with LC-MS/MS. Mol. Cell Proteomics 2012, 11, 187-201. [CrossRef]

153. Chen, R.Q.; Yang, Q.K.; Lu, B.W.; Yi, W.; Cantin, G.; Chen, Y.L.; Fearns, C.; Yates, J.R., III; Lee, J.D. CDC25B mediates rapamycininduced oncogenic responses in cancer cells. Cancer Res. 2009, 69, 2663-2668. [PubMed]

154. Malec, V.; Coulson, J.M.; Urbe, S.; Clague, M.J. Combined Analyses of the VHL and Hypoxia Signaling Axes in an Isogenic Pairing of Renal Clear Cell Carcinoma Cells. J. Proteome Res. 2015, 14, 5263-5272. [CrossRef] [PubMed]

155. Bennetzen, M.V.; Larsen, D.H.; Bunkenborg, J.; Bartek, J.; Lukas, J.; Andersen, J.S. Site-specific phosphorylation dynamics of the nuclear proteome during the DNA damage response. Mol. Cell Proteomics 2010, 9, 1314-1323. [PubMed]

156. Stuart, S.A.; Houel, S.; Lee, T.; Wang, N.; Old, W.M.; Ahn, N.G. A Phosphoproteomic Comparison of B-RAFV600E and MKK1/2 Inhibitors in Melanoma Cells. Mol. Cell Proteomics 2015, 14, 1599-1615. [CrossRef]

157. Dephoure, N.; Zhou, C.; Villen, J.; Beausoleil, S.A.; Bakalarski, C.E.; Elledge, S.J.; Gygi, S.P. A quantitative atlas of mitotic phosphorylation. Proc. Natl. Acad. Sci. USA 2008, 105, 10762-10767. [CrossRef]

158. Sharma, K.; D’Souza, R.C.; Tyanova, S.; Schaab, C.; Wisniewski, J.R.; Cox, J.; Mann, M. Ultradeep human phosphoproteome reveals a distinct regulatory nature of Tyr and Ser/Thr-based signaling. Cell Rep. 2014, 8, 1583-1594. [CrossRef]

159. Zhou, H.; Di, P.S.; Preisinger, C.; Peng, M.; Polat, A.N.; Heck, A.J.; Mohammed, S. Toward a comprehensive characterization of a human cancer cell phosphoproteome. J. Proteome Res. 2013, 12, 260-271. [CrossRef] 
160. Weinberg, R.A. The retinoblastoma protein and cell cycle control. Cell 1995, 81, 323-330. [CrossRef]

161. Connell-Crowley, L.; Harper, J.W.; Goodrich, D.W. Cyclin D1/Cdk4 regulates retinoblastoma protein-mediated cell cycle arrest by site-specific phosphorylation. Mol. Biol. Cell 1997, 8, 287-301. [CrossRef]

162. Narasimha, A.M.; Kaulich, M.; Shapiro, G.S.; Choi, Y.J.; Sicinski, P.; Dowdy, S.F. Cyclin D activates the Rb tumor suppressor by mono-phosphorylation. Elife 2014, 3, e02872. [CrossRef]

163. Sanidas, I.; Morris, R.; Fella, K.A.; Rumde, P.H.; Boukhali, M.; Tai, E.C.; Ting, D.T.; Lawrence, M.S.; Haas, W.; Dyson, N.J. A Code of Mono-phosphorylation Modulates the Function of RB. Mol. Cell 2019, 73, 985-1000.

164. Buchkovich, K.; Duffy, L.A.; Harlow, E. The retinoblastoma protein is phosphorylated during specific phases of the cell cycle. Cell 1989, 58, 1097-1105. [CrossRef]

165. Ezhevsky, S.A.; Nagahara, H.; Vocero-Akbani, A.M.; Gius, D.R.; Wei, M.C.; Dowdy, S.F. Hypo-phosphorylation of the retinoblastoma protein (pRb) by cyclin D:Cdk4/6 complexes results in active pRb. Proc. Natl. Acad. Sci. USA 1997, 94, 10699-10704. [CrossRef]

166. Zarkowska, T.; Mittnacht, S. Differential phosphorylation of the retinoblastoma protein by G1/S cyclin-dependent kinases. J. Biol. Chem. 1997, 272, 12738-12746. [CrossRef]

167. Ren, S.; Rollins, B.J. Cyclin C/cdk3 promotes Rb-dependent G0 exit. Cell 2004, 117, 239-251. [CrossRef]

168. Burke, J.R.; Hura, G.L.; Rubin, S.M. Structures of inactive retinoblastoma protein reveal multiple mechanisms for cell cycle control. Genes Dev. 2012, 26, 1156-1166. [CrossRef]

169. Olsen, J.V.; Vermeulen, M.; Santamaria, A.; Kumar, C.; Miller, M.L.; Jensen, L.J.; Gnad, F.; Cox, J.; Jensen, T.S.; Nigg, E.A.; et al. Quantitative phosphoproteomics reveals widespread full phosphorylation site occupancy during mitosis. Sci. Signal. 2010, 3, ra3. [CrossRef]

170. Witkiewicz, A.K.; Ertel, A.; McFalls, J.; Valsecchi, M.E.; Schwartz, G.; Knudsen, E.S. RB-pathway disruption is associated with improved response to neoadjuvant chemotherapy in breast cancer. Clin. Cancer Res. 2012, 18, 5110-5122. [CrossRef]

171. Zagorski, W.A.; Knudsen, E.S.; Reed, M.F. Retinoblastoma deficiency increases chemosensitivity in lung cancer. Cancer Res. 2007, 67, 8264-8273. [CrossRef]

172. Coussy, F.; El-Botty, R.; Chateau-Joubert, S.; Dahmani, A.; Montaudon, E.; Leboucher, S.; Morisset, L.; Painsec, P.; Sourd, L.; Huguet, L.; et al. BRCAness, SLFN11, and RB1 loss predict response to topoisomerase I inhibitors in triple-negative breast cancers. Sci. Transl. Med. 2020, 12, eaax2625. [CrossRef]

173. Martinez-Limon, A.; Joaquin, M.; Caballero, M.; Posas, F.; de Nadal, E. The p38 Pathway: From Biology to Cancer Therapy. Int. J. Mol. Sci. 2020, 21, 1913. [CrossRef]

174. Faust, D.; Schmitt, C.; Oesch, F.; Oesch-Bartlomowicz, B.; Schreck, I.; Weiss, C.; Dietrich, C. Differential p38-dependent signalling in response to cellular stress and mitogenic stimulation in fibroblasts. Cell Commun. Signal. 2012, 10, 6. [CrossRef]

175. Joaquin, M.; de Nadal, E.; Posas, F. An RB insensitive to CDK regulation. Mol. Cell. Oncol. 2016, 4, e1268242. [CrossRef]

176. Yu-Lee, L.Y.; Yu, G.; Lee, Y.C.; Lin, S.C.; Pan, J.; Pan, T.; Yu, K.J.; Liu, B.; Creighton, C.J.; Rodriguez-Canales, J.; et al. OsteoblastSecreted Factors Mediate Dormancy of Metastatic Prostate Cancer in the Bone via Activation of the TGFbetaRIII-p38MAPKpS249/T252RB Pathway. Cancer Res. 2018, 78, 2911-2924. [CrossRef]

177. Wang, R.; Ferraris, J.D.; Izumi, Y.; Dmitrieva, N.; Ramkissoon, K.; Wang, G.; Gucek, M.; Burg, M.B. Global discovery of high-NaCl-induced changes of protein phosphorylation. Am. J. Physiol Cell Physiol. 2014, 307, C442-C454. [CrossRef]

178. Carnevale, J.; Palander, O.; Seifried, L.A.; Dick, F.A. DNA damage signals through differentially modified E2F1 molecules to induce apoptosis. Mol. Cell Biol. 2012, 32, 900-912. [CrossRef]

179. Tomas-Loba, A.; Manieri, E.; Gonzalez-Teran, B.; Mora, A.; Leiva-Vega, L.; Santamans, A.M.; Romero-Becerra, R.; Rodriguez, E.; Pintor-Chocano, A.; Feixas, F.; et al. p38gamma is essential for cell cycle progression and liver tumorigenesis. Nature 2019, 568, 557-560. [CrossRef]

180. Gong, X.; Du, J.; Parsons, S.H.; Merzoug, F.F.; Webster, Y.; Iversen, P.W.; Chio, L.C.; Van Horn, R.D.; Lin, X.; Blosser, W.; et al. Aurora A Kinase Inhibition Is Synthetic Lethal with Loss of the RB1 Tumor Suppressor Gene. Cancer Discov. 2019, 9, $248-263$. [CrossRef]

181. Oser, M.G.; Fonseca, R.; Chakraborty, A.A.; Brough, R.; Spektor, A.; Jennings, R.B.; Flaifel, A.; Novak, J.S.; Gulati, A.; Buss, E.; et al. Cells Lacking the RB1 Tumor Suppressor Gene Are Hyperdependent on Aurora B Kinase for Survival. Cancer Discov. 2019, 9, 230-247. [CrossRef]

182. Lyu, J.; Yang, E.J.; Zhang, B.; Wu, C.; Pardeshi, L.; Shi, C.; Mou, P.K.; Liu, Y.; Tan, K.; Shim, J.S. Synthetic lethality of RB1 and aurora $\mathrm{A}$ is driven by stathmin-mediated disruption of microtubule dynamics. Nat. Commun. 2020, 11, 5105. [CrossRef]

183. Alberts, A.S.; Thorburn, A.M.; Shenolikar, S.; Mumby, M.C.; Feramisco, J.R. Regulation of cell cycle progression and nuclear affinity of the retinoblastoma protein by protein phosphatases. Proc. Natl. Acad. Sci. USA 1993, 90, 388-392. [CrossRef]

184. Ludlow, J.W.; Glendening, C.L.; Livingston, D.M.; DeCarprio, J.A. Specific enzymatic dephosphorylation of the retinoblastoma protein. Mol. Cell Biol. 1993, 13, 367-372.

185. Dohadwala, M.; da Cruz e Silva, E.F.; Hall, F.L.; Williams, R.T.; Carbonaro-Hall, D.A.; Nairn, A.C.; Greengard, P.; Berndt, N. Phosphorylation and inactivation of protein phosphatase 1 by cyclin-dependent kinases. Proc. Natl. Acad. Sci. USA 1994, 91, 6408-6412. [CrossRef]

186. Berndt, N.; Dohadwala, M.; Liu, C.W. Constitutively active protein phosphatase 1alpha causes Rb-dependent G1 arrest in human cancer cells. Curr. Biol. 1997, 7, 375-386. [CrossRef] 
187. Tamrakar, S.; Ludlow, J.W. The carboxyl-terminal region of the retinoblastoma protein binds non-competitively to protein phosphatase type 1alpha and inhibits catalytic activity. J. Biol. Chem. 2000, 275, 27784-27789. [CrossRef]

188. Bianchi, M.; Villa-Moruzzi, E. Binding of phosphatase-1 delta to the retinoblastoma protein pRb involves domains that include substrate recognition residues and a pRB binding motif. Biochem. Biophys. Res. Commun. 2001, 280, 1-3. [CrossRef]

189. Tamrakar, S.; Mittnacht, S.; Ludlow, J.W. Binding of select forms of pRB to protein phosphatase type 1 independent of catalytic activity. Oncogene 1999, 18, 7803-7809.

190. Rubin, E.; Mittnacht, S.; Villa-Moruzzi, E.; Ludlow, J.W. Site-specific and temporally-regulated retinoblastoma protein dephosphorylation by protein phosphatase type 1. Oncogene 2001, 20, 3776-3785. [CrossRef]

191. Kiss, A.; Lontay, B.; Becsi, B.; Markasz, L.; Olah, E.; Gergely, P.; Erdodi, F. Myosin phosphatase interacts with and dephosphorylates the retinoblastoma protein in THP-1 leukemic cells: Its inhibition is involved in the attenuation of daunorubicin-induced cell death by calyculin-A. Cell Signal. 2008, 20, 2059-2070. [CrossRef]

192. Udho, E.; Tedesco, V.C.; Zygmunt, A.; Krucher, N.A. PNUTS (phosphatase nuclear targeting subunit) inhibits retinoblastomadirected PP1 activity. Biochem. Biophys. Res. Commun. 2002, 297, 463-467. [CrossRef]

193. Verdugo-Sivianes, E.M.; Carnero, A. Role of the Holoenzyme PP1-SPN in the Dephosphorylation of the RB Family of Tumor Suppressors During Cell Cycle. Cancers 2021, 13, 2226. [CrossRef]

194. Garriga, J.; Jayaraman, A.L.; Limon, A.; Jayadeva, G.; Sotillo, E.; Truongcao, M.; Patsialou, A.; Wadzinski, B.E.; Grana, X A dynamic equilibrium between CDKs and PP2A modulates phosphorylation of pRB, p107 and p130. Cell Cycle 2004, 3, 1320-1330. [CrossRef]

195. Avni, D.; Yang, H.; Martelli, F.; Hofmann, F.; ElShamy, W.M.; Ganesan, S.; Scully, R.; Livingston, D.M. Active localization of the retinoblastoma protein in chromatin and its response to $S$ phase DNA damage. Mol. Cell 2003, 12, 735-746. [CrossRef]

196. Cicchillitti, L.; Fasanaro, P.; Biglioli, P.; Capogrossi, M.C.; Martelli, F. Oxidative stress induces protein phosphatase 2A-dependent dephosphorylation of the pocket proteins pRb, p107, and p130. J. Biol. Chem. 2003, 278, 19509-19517. [CrossRef]

197. Voorhoeve, P.M.; Watson, R.J.; Farlie, P.G.; Bernards, R.; Lam, E.W. Rapid dephosphorylation of p107 following UV irradiation. Oncogene 1999, 18, 679-688. [CrossRef]

198. Choudhary, C.; Kumar, C.; Gnad, F.; Nielsen, M.L.; Rehman, M.; Walther, T.C.; Olsen, J.V.; Mann, M. Lysine acetylation targets protein complexes and co-regulates major cellular functions. Science 2009, 325, 834-840. [CrossRef]

199. Chan, H.M.; Krstic-Demonacos, M.; Smith, L.; Demonacos, C.; La Thangue, N.B. Acetylation control of the retinoblastoma tumour-suppressor protein. Nat. Cell Biol. 2001, 3, 667-674. [CrossRef]

200. Lin, W.C.; Lin, F.T.; Nevins, J.R. Selective induction of E2F1 in response to DNA damage, mediated by ATM-dependent phosphorylation. Genes Dev. 2001, 15, 1833-1844.

201. Stevens, C.; Smith, L.; La Thangue, N.B. Chk2 activates E2F-1 in response to DNA damage. Nat. Cell Biol. $2003,5,401-409$. [CrossRef]

202. Carr, S.M.; Munro, S.; Zalmas, L.P.; Fedorov, O.; Johansson, C.; Krojer, T.; Sagum, C.A.; Bedford, M.T.; Oppermann, U.; La Thangue, N.B. Lysine methylation-dependent binding of 53BP1 to the pRb tumor suppressor. Proc. Natl. Acad. Sci. USA 2014, 111, 11341-11346. [CrossRef] [PubMed]

203. Trere, D.; Brighenti, E.; Donati, G.; Ceccarelli, C.; Santini, D.; Taffurelli, M.; Montanaro, L.; Derenzini, M. High prevalence of retinoblastoma protein loss in triple-negative breast cancers and its association with a good prognosis in patients treated with adjuvant chemotherapy. Ann. Oncol. 2009, 20, 1818-1823. [CrossRef] [PubMed]

204. Robinson, T.J.; Liu, J.C.; Vizeacoumar, F.; Sun, T.; Maclean, N.; Egan, S.E.; Schimmer, A.D.; Datti, A.; Zacksenhaus, E. RB1 status in triple negative breast cancer cells dictates response to radiation treatment and selective therapeutic drugs. PLoS ONE 2013, 8, e78641. [CrossRef] [PubMed] 